\title{
Inflammation and pancreatic cancer: molecular and functional interactions between S100A8, S100A9, NT-S100A8 and TGFß1
}

Daniela Basso ${ }^{1 *}$, Dania Bozzato ${ }^{2 \dagger}$, Andrea Padoan ${ }^{2 \dagger}$, Stefania $\mathrm{Moz}^{2 \dagger}$, Carlo-Federico Zambon ${ }^{2}$, Paola Fogar ${ }^{1}$, Eliana Greco², Michele Scorzeto ${ }^{3}$, Francesca Simonato², Filippo Navaglia', Matteo Fassan², Michela Pelloso², Sirio Dupont ${ }^{4}$, Sergio Pedrazzoli ${ }^{5}$, Ambrogio Fassina ${ }^{2}$ and Mario Plebani ${ }^{1,2}$

\begin{abstract}
Background: In order to gain further insight on the crosstalk between pancreatic cancer (PDAC) and stromal cells, we investigated interactions occurring between TGF 31 and the inflammatory proteins S100A8, S100A9 and NTS100A8, a PDAC-associated S100A8 derived peptide, in cell signaling, intracellular calcium $\left(\mathrm{Ca}_{i}^{2+}\right)$ and epithelial to mesenchymal transition (EMT). NF-KB, Akt and mTOR pathways, $\mathrm{Ca}_{i}^{2+}$ and EMT were studied in well (Capan1 and BxPC3) and poorly differentiated (Panc1 and MiaPaCa2) cell lines.

Results: NT-S100A8, one of the low molecular weight N-terminal peptides from S100A8 to be released by PDAC-derived proteases, shared many effects on NF-KB, Akt and mTOR signaling with S100A8, but mainly with TGF $\beta 1$. The chief effects of S100A8, S100A9 and NT-S100A8 were to inhibit NF-KB and stimulate mTOR; the molecules inhibited Akt in Smad4expressing, while stimulated Akt in Smad4 negative cells. By restoring Smad4 expression in BxPC3 and silencing it in MiaPaCa2, S100A8 and NT-S100A8 were shown to inhibit NF-KB and Akt in the presence of an intact TGF $\beta 1$ canonical signaling pathway. TGF $\beta 1$ counteracted S100A8, S100A9 and NT-S100A8 effects in Smad4 expressing, not in Smad4 negative cells, while it synergized with NT-S100A8 in altering $\mathrm{Ca}_{\mathrm{i}}^{2+}$ and stimulating PDAC cell growth. The effects of TGF $\beta 1$ on both EMT (increased Twist and decreased N-Cadherin expression) and $\mathrm{Ca}_{\mathrm{i}}^{2+}$ were antagonized by S100A9, which formed heterodimers with TGF $\beta 1$ (MALDI-TOF/MS and co-immuno-precipitation).
\end{abstract}

Conclusions: The effects of S100A8 and S100A9 on PDAC cell signaling appear to be cell-type and context dependent. NTS100A8 mimics the effects of TGF $\beta 1$ on cell signaling, and the formation of complexes between TGF $\beta 1$ with S100A9 appears to be the molecular mechanism underlying the reciprocal antagonism of these molecules on cell signaling, $\mathrm{Ca}_{\mathrm{i}}^{2+}$ and EMT.

Keywords: Akt, Calcium, Calcium binding proteins, Epithelial to mesenchymal transition, Mass spectrometry (MS), Matrix metalloproteinase (MMP), mTOR, Pancreatic cancer, SMAD transcription factor

\section{Lay abstract}

\section{Background}

S100A8/A9, NT-S100A8 are overexpressed in PDAC stroma when cancer cells express Smad4, suggesting that they are linked with TGF $\beta 1$ signalling.

\section{Results}

S100A8 inhibits NF-kB and activates Akt in Smad4+, not in Smad4- cells. NT-S100A8 mimics TGF $\beta 1$. S100A9 binds to and antagonizes TGF $\beta 1$.

\footnotetext{
* Correspondence: daniela.basso@sanita.padova.it

${ }^{\dagger}$ Equal contributors

'Department of Laboratory Medicine, University-Hospital of Padova, Via Giustiniani 2, 35128 Padova, Italy

Full list of author information is available at the end of the article
}

\section{Conclusion}

S100A8 signaling in PDAC cells is Smad4-dependent.

\section{Significance}

Novel interactions between S100 proteins and TGF $\beta 1$ signaling in PDAC have been identified.

\section{Background}

Pancreatic ductal adenocarcinoma (PDAC), the fourth leading cause of cancer-related mortality in the U.S.A. and Europe [1,2], is an extremely aggressive form of cancer [3]. When the widely known PDAC precursor, PanIN, progresses from stage I to stage III, it accumulates cellular atypia and a series of genetic alterations, including activation of

\section{Biomed Central}

(c) 2014 Basso et al.; licensee BioMed Central Ltd. This is an Open Access article distributed under the terms of the Creative Commons Attribution License (http://creativecommons.org/licenses/by/2.0), which permits unrestricted use, distribution, and reproduction in any medium, provided the original work is properly credited. The Creative Commons Public Domain Dedication waiver (http://creativecommons.org/publicdomain/zero/1.0/) applies to the data made available in this article, unless otherwise stated. 
oncogenic $k$-ras and inactivation of tumor suppressors $p 16$ Ink $4 a$ and $p 53$ [4]. As clearly demonstrated in genetically engineered mouse models of PDAC progression, the pancreatic epithelium-specific expression of $k$-ras (KrasG12D) induces PanIN lesions that can progress to PDAC, the average latency being more than one year; K-rasG12D expression coupled with the homozygous or heterozygous deletion of the tumor suppressor genes $p 53$ and/or p16Ink4a underlies short latency PDAC [5-7]. In humans and mice, PDAC progression is characterized by the inactivation of the tumor suppressor gene, Smad4 [4,8]. In most cases of PDAC, $k$-ras, p16Ink $4 a$ and $p 53$ mutations are present [8], whereas in about $50 \%$ of cases, Smad4 inactivation due to gene deletion or mutations associated with loss of heterozygosity, is identified [9]. When Smad4 is inactivated, PDAC is associated with widespread metastases [10] and a poorer prognosis [11].

The transcription factor encoded by Smad4 is a central effector of the transforming growth factor beta 1 (TGF 31 ) signaling pathway [12], which is one of the 12 core signaling pathways reported to be altered in most PDAC cases [13]. TGF $\beta 1$ is critically involved in cancer initiation and progression through tumor cell autonomous signaling and interactions with the tumor microenvironment [14]. Coupled with the type II TGF $\beta$ receptor, TGF $\beta 1$ activates the type I receptor, which then triggers the canonical and/or non-canonical pathways. In the canonical pathway it recruits and phosphorylates receptor Smads (Smad2 and Smad3) thus facilitating their interaction with Smad4 and its subsequent nuclear translocation, while in the non-canonical pathway it activates a series of signaling cascades including Ras, PI3K and NF-kB $[12,15]$. The effects of TGF $\beta 1$ stimulation vary in different settings, since the response to this molecule is cell-type and context dependent. In PDAC, TGF $\beta 1$ acts as a tumor suppressor by inhibiting cancer cell growth, and as a tumor promoter by dampening host immune surveillance while inducing an epithelial to mesenchymal transition (EMT) and a stromal expansion [16-19]. EMT confers on tumor cells a capacity to migrate and metastasize [17], while stromal expansion, which is marked in PDAC [20], creates a favorable setting for tumor cell migration and disease progression [21,22].

The TGF $\beta 1$ molecule is a crucial component in understanding tumor-stromal interactions: although produced by tumor cells, it is overexpressed by stromal cells mainly at the invasive front area of human PDAC [23]; moreover, in an experimental PDAC mouse model TGF $\beta 1$ was shown to mediate cancer cell derived $\mathrm{Cxcr} 2$ stimulatory effects on pancreatic fibroblasts to express Ctgf, which is greatly involved in PDAC progression [21].

In investigating tumor-stromal interactions, particular attention should be paid to the inflammatory proteins S100A8 and S100A9 [24], which are encoded by genes clustered on chromosome 1q21 [25]. This chromosome region [26,27] as well as S100A8/A9 TLR4 and RAGE receptors [28-30], has been associated with cancer development and metastasis. In PDAC, S100A8/A9 are overexpressed by infiltrating inflammatory cells [31,32], the levels of expression appearing to be correlated with TGF $\beta 1$ signaling: Smad4 depletion is associated with reduced S100A8 (not S100A9) positive infiltrating inflammatory cells $[31,33]$ and, conversely, these proteins are expressed by PDAC cell lines only in cases of Smad4 inactivation [34]. The existence of an interaction between S100A8, S100A9 and the TGF $\beta 1$ canonical signaling pathway is supported by the finding that both molecules induce Smad1 and Smad2 phosphorylation through a RAGE dependent mechanism [33]. Since S100A8 and S100A9 are calcium binding proteins, the complexity of their effects on tumor biology may depend not only on TLR4 and/or RAGE ligation, but also on alterations in intracellular calcium fluxes and/or concentrations, demonstrated to occur in pancreatic $\beta$-cells exposed to the $14 \mathrm{~N}$-terminal aminoacid peptide of S100A8 (NT-S100A8), which we isolated from PDAC tissues of patients with PDAC-associated diabetes mellitus [34]. Variations in intracellular calcium, critical events that regulate cancer cell proliferation and progression, may be explained by the complex effects of calcium on different cancer cell signaling pathways, including the Ca-calmodulin protein kinase cascade, Akt, mTOR and TGF $\beta 1$ [35-40]. It is not known whether the release of NTS100A8 from the entire S100A8 is a PDAC-driven event and whether these two molecules, and the S100A8 binding partner S100A9, interact with TGF 31 in altering PDAC signaling pathways and cell biology.

The end points of the present study were therefore to ascertain whether: 1. PDAC cells express S100A8/A9 proteins and PDAC-derived proteases fragment S100A8/A9 causing the release of their $\mathrm{N}$-terminal peptides, with a special focus on NT-S100A8; 2. TGF $\beta 1$ and/or an intact TGF $\beta 1$ signaling pathway influence the S100A8/A9 and NT-S100A8 effects on Akt, NF- $\mathrm{B}$ and mTOR signaling pathways in PDAC cells; 3. S100A8/A9 and NT-S100A8 affect intracellular calcium fluxes in a TGF $\beta 1$ dependent or independent manner; 4. S100A8/A9 and NT-S100A8 modify PDAC cell proliferation, apoptosis and the EMT process directly and/or by interfering with TGF $\beta 1$ activity.

In the present study we demonstrate that NT-S100A8 and S100A8 preferentially activate mTOR in cells with wild type Smad4 expression and NF- $\mathrm{kB}$ in Smad4 negative cells, and that, by forming complexes, S100A8/A9 and TGF $\beta 1$ antagonize the effects of each other on intracellular calcium and EMT.

\section{Results}

Metastatic PDAC cell lines have high S100A8/A9 expression A comparative quantification was made of S100A8 and S100A9 mRNA expression by real time PCR and 
referred to their respective expression levels by the PDAC metastatic SUIT2 cell line (Table 1). Capan1 expressed high S100A8 and S100A9 mRNA levels. Mia$\mathrm{PaCa} 2$ and Panc1 did not express detectable S100A8 mRNA levels, and had a S100A9 expression 100 fold lower than SUIT2. BxPC3 did not express detectable levels of either S100A8 or S100A9 mRNA, while the stable transfected BxPC3-SMAD4+ cell line (BxPC3SMAD4+) had S100A9 (not S100A8) expression comparable to that of MiaPaCa2 and Panc1 (100 fold lower than SUIT2). S100A8/A9 receptor RAGE expression, found in all studied cell lines, was lower in BxPC3 and Panc1 than in Capan1 and MiaPaCa2 (Additional file 1: Figure S1).

\section{S100A8 proteolysis is induced by pancreatic cancer cell conditioned media}

Figure 1 shows low molecular weight MALDI-TOF/MS spectra obtained after 24 hours' incubation at $37^{\circ} \mathrm{C}$ of S100A8 in complete control culture medium, Capan1 conditioned medium (CM) and Capan1 CM obtained after treatment with the MMPs inhibitor Ukrain [41]. On incubating S100A8 with Capan1 CM, a new peptide was found at $2280 \mathrm{~m} / \mathrm{z}$ (Figure 1D). This peptide progressively accumulated as the incubation time of S100A8 in Capan1 CM increased, the kinetic of its appearance being inverse with respect to that of S100A8 degradation (Figure 2). The $2280 \mathrm{~m} / \mathrm{z}$ peptide was not detected when S100A8 was incubated in Ukrain treated Capan1 CM (Figure 1E). At MALDI-TOF-MS/MS analysis using denovo sequencing, the $2280 \mathrm{~m} / \mathrm{z}$ peptide was identified as the 1-19 N-terminal aminoacid sequence of S100A8 (Additional file 2: Figure S2). The 1-19 N-terminal aminoacid sequence of S100A8 was then synthesized and incubated for $1,2,3,4,5,6,12$ and 24 hours in the control, Capan 1 and $\mathrm{BxPC} 3 \mathrm{CM}$ at $37^{\circ} \mathrm{C}$. At the end of all incubation times, MALDI-TOF/MS analysis was made in the low molecular weight range $(650-3000 \mathrm{~m} / \mathrm{z})$. In the presence of both BxPC3 and Capan1 CM, after 24 hours' incubation the parental 19 aminoacid peptide disappeared, while a series of new peptides were detected, the most

Table 1 S100A8 and S100A9 mRNA relative quantification in PDAC cell lines

\begin{tabular}{|c|c|c|c|}
\hline \multirow[t]{2}{*}{$\begin{array}{l}\text { PDAC cell } \\
\text { lines }\end{array}$} & \multirow{2}{*}{$\begin{array}{l}\text { S100A8 fold } \\
\text { increase } \\
\text { Mean } \pm \text { SD }\end{array}$} & \multirow{2}{*}{$\begin{array}{l}\text { S100A9 fold } \\
\text { increase } \\
\text { Mean } \pm \text { SD }\end{array}$} & \multirow[t]{2}{*}{$\begin{array}{l}\text { Reference } \\
\text { (SUIT2) }\end{array}$} \\
\hline & & & \\
\hline $\mathrm{BxPC} 3$ & Absent & Absent & 1 \\
\hline Capan1 & $1736 \pm 230$ & $582.92 \pm 18.83$ & 1 \\
\hline MiaPaCa2 & Absent & $0.01 \pm 0.000798$ & 1 \\
\hline Panc1 & Absent & $0.01 \pm 0.000997$ & 1 \\
\hline BxPC3-Smad4+ & Absent & $0.01 \pm 0.003447$ & 1 \\
\hline
\end{tabular}

The PDAC metastatic SUIT2 cell line was used as reference (S100A8 $C_{T}=36.46 \pm$ 0.34 cycles; $\mathrm{S} 100 \mathrm{~A} 9 \mathrm{C}_{\mathrm{T}}=32.01 \pm 0.53$ cycles; mean \pm SD from three independent experiments, each made in duplicate). abundant being those at 1030, 1252, 1435, 1852, $1873 \mathrm{~m} / \mathrm{z}$; two of these, at 1435 and $1852 \mathrm{~m} / \mathrm{z}$, were also detected in the spectra from S100A8 incubated with Capan1 CM (Figure 1D). Using the proteomic tool, FindPept, the above listed peptides were identified as the $2-10,10-19,8-19$, 1-16 and 3-18 aminoacid sequences of S100A8, respectively. At MALDI-TOF-MS/MS analysis of the $1435 \mathrm{~m} / \mathrm{z}$ peptide, its correspondence to the 8-19 S100A8 aminoacid sequence was confirmed (Additional file 3: Figure S3). Figure 3 shows the variations over time in the abundance of 1030 and $1435 \mathrm{~m} / \mathrm{z}$, and of the 1852 and $1873 \mathrm{~m} / \mathrm{z}$ peptides in BxPC3 and Capan1 CM.

\section{Effects and interactions of $\mathrm{S} 100$ proteins and TGF $\beta 1$ on NF-kB, Akt, mTOR and STAT signaling in PDAC cells}

To obtain a representative picture "in vitro" of the complexity of human PDAC, our study included the four pancreatic cancer cell lines BxPC3, Capan1, MiaPaCa2 and Panc1, which differ in their genetic make-up, grade and metastatic potential [42]. Using these cell lines the effects of S100A8, S100A9 and of NT-S100A8, alone or combined with TGF $\beta 1$, on NF-kB, Akt, mTOR and STAT signaling pathways were evaluated. The response to insulin stimulation was also analyzed as a reference for the PI3K pathway. To investigate NF- $\mathrm{KB}$ signaling, we analyzed $\mathrm{I} \kappa \mathrm{B} \alpha$ phosphorylation (Figure 4) that, when enhanced, is associated with $I_{\kappa} B \alpha$ ubiquitination and the nuclear translocation of NF- $\mathrm{kB}$ dimers, which activate the transcription of their target genes.

S100A8, S100A9, S100A8/A9 and NT-S100A8 exerted overlapping effects on NF- $\mathrm{B}$ signaling: they reduced $\mathrm{I} \kappa \mathrm{B} \alpha$ phosphorylation in Capan1, MiaPaCa2 and Panc1, not in BxPC3. TGF $\beta 1$ had no significant effects on $\mathrm{I} k \mathrm{~B} \alpha$ phosphorylation. We then studied the Akt signaling pathway by western blot analysis of $\mathrm{Thr}^{308}$, induced by the PI3K, and $\mathrm{Ser}^{473}$, a target site of mTORC2 [43] (Figure 5). S100A8, S100A9 and S100A8/A9 uniformly induced in BxPC3, and reduced in the other cell lines, Akt Thr ${ }^{308}$ phosphorylation. These molecules, but mainly S100A8 caused also a reduced Akt Ser $^{473}$ phosphorylation in Capan1, MiaPaCa2 and Panc1 cells. NT-S100A8, similarly to S100A8, reduced in Capan1 and MiaPaCa2 $\mathrm{Thr}^{308}$ phosphorylation, but unlike S100A8 this peptide augmented in the same cell lines $\operatorname{Ser}^{473}$. TGF $\beta 1$ co-treatment caused no relevant modification in findings for the effects of S100 calcium binding proteins on Akt phosphorylation, with the exception of S100A8 and NT-S100A8 effects in Panc1 cells. mTOR signaling was then studied by analyzing mTOR Ser ${ }^{2448}$, mTOR Ser ${ }^{2481}$ and S6 Ribosomal Protein (S6RP) phosphorylation (Figure 6). S100A8 and S100A9 induced mTOR Ser $^{2448}$ phosphorylation in all cell lines and $\operatorname{Ser}^{2481}$ in BxPC3 and Capan1; S100A8/A9 induced in BxPC3, MiaPaCa2 and Panc1, but reduced in Capan1, mTOR Ser ${ }^{2481}$ and $\operatorname{Ser}^{2448}$ phosphorylation and 


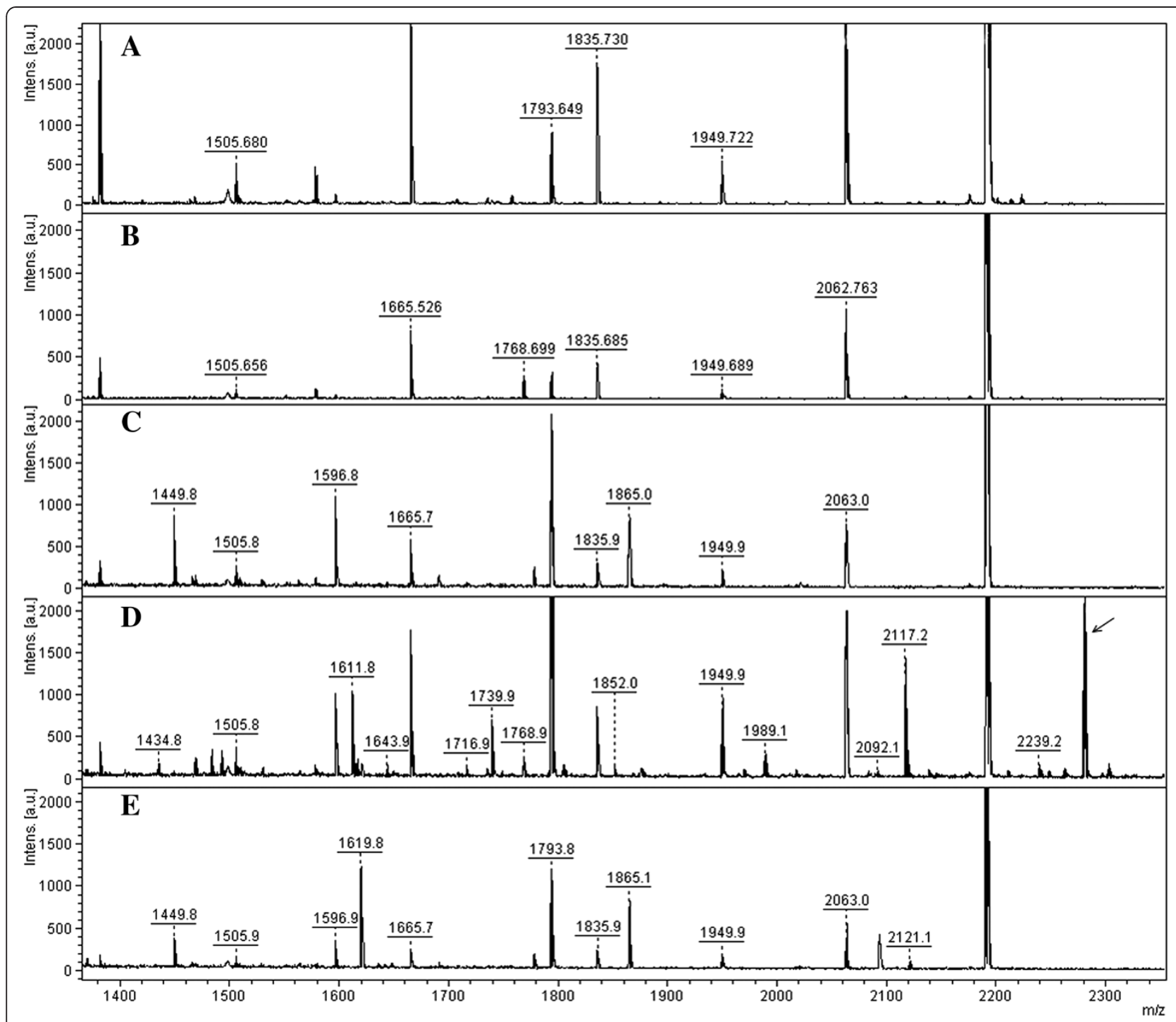

Figure 1 S100A8 is fragmented by PDAC cell conditioned media. MALDI-TOF/MS low-molecular weight spectra obtained after overnight incubation of S100A8 in complete control culture medium, in Capan1 conditioned media (CM) and in Ukrain treated Capan1 CM. A: complete control medium; B: complete control medium added with 3 HM S100A8; C: Capan1 conditioned medium; D: Capan1 conditioned medium with added 3 MM S100A8; E: Ukrain treated Capan1 conditioned medium with added $3 \mu \mathrm{M} \mathrm{S100A8}$. The complete control medium was incubated at $37^{\circ} \mathrm{C}$ in a cell culture incubator without cells for 96 hours with $1 \% \mathrm{FCS}$ and $0.1 \%$ gentamycin, in the same conditions as CM. The arrow indicates the $2280 \mathrm{~m} / \mathrm{z}$ peptide.

A

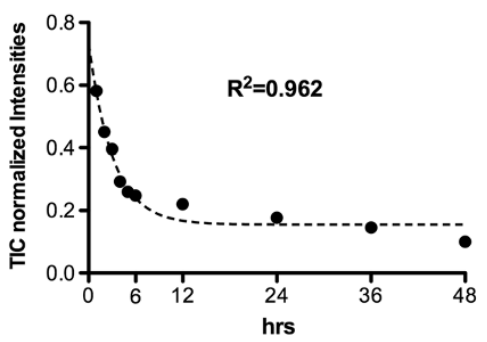

B

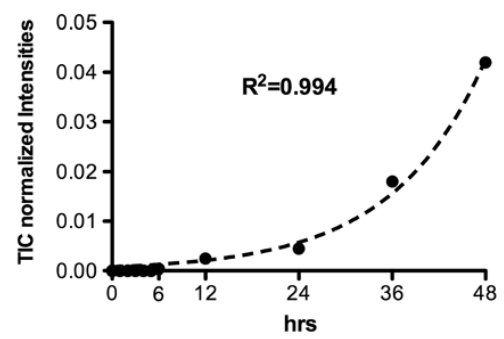

Figure 2 Degradation kinetics of S100A8 by PDAC cell conditioned media. S100A8 ( $3 \mu \mathrm{M})$ was incubated with Capan 1 conditioned media for $1,2,3,4,5,6,12,24,36$ and 48 hours at $37^{\circ} \mathrm{C}$ before MALDI-TOF/MS analyses. The intensities of S100A8 and of the main degradation peptide identified (2280 m/z) were normalized to total ion current (TIC). A: S100A8 TIC normalized intensities; B: 2280 m/z peptide TIC normalized intensities. The curve kinetics were obtained by exponential fitting. 

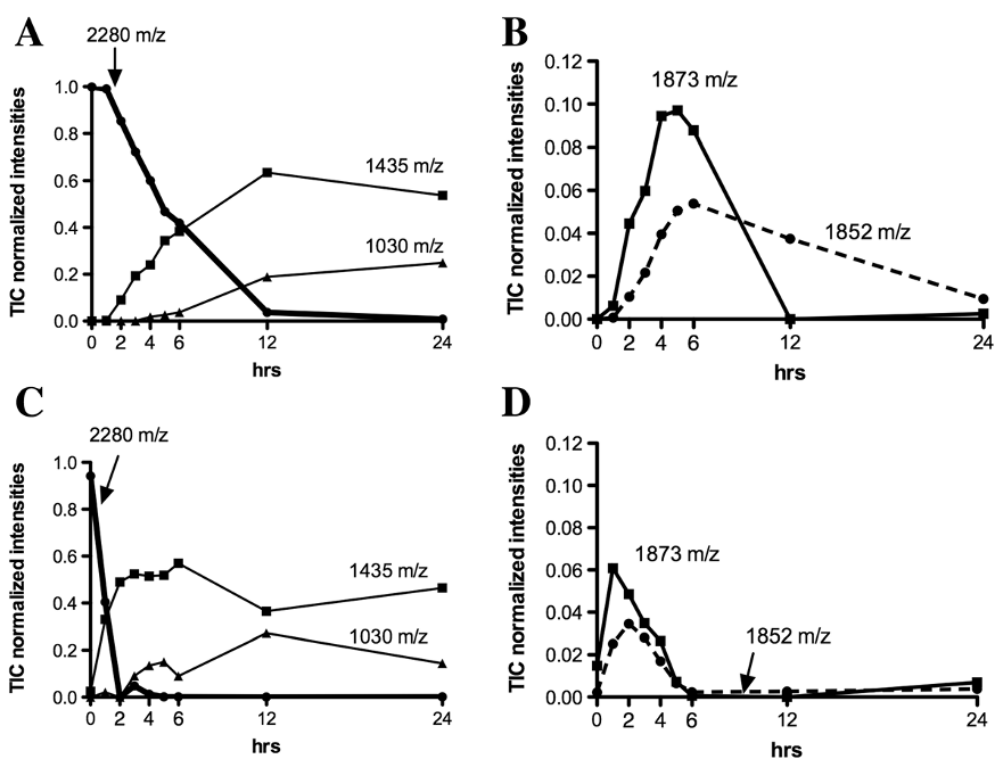

D

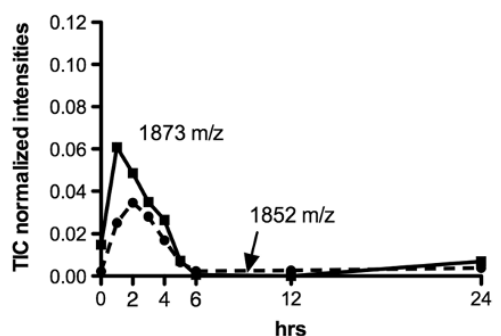

Figure 3 Degradation kinetics of the $\mathbf{2} 280 \mathrm{~m} / \mathbf{z}$ peptide by PDAC cell conditioned media. The $2280 \mathrm{~m} / \mathrm{z}$ peptide (200 $\mu \mathrm{M}$ ), encompassing the 1-19 aminoacid sequence of S100A8, was incubated with BxPC3 (A and B) or Capan1 (C and D) conditioned media for 1, 2, 3, 4, 5, 6, 12 and 24 hours at $37^{\circ} \mathrm{C}$ before MALDI-TOF/MS analyses. The intensities of the main five peptides identified were normalized to total ion current (TIC). In non-conditioned media the abundance of the parental 19 aminoacid peptide at $2280 \mathrm{~m} / \mathrm{z}$ was 0.99 both at time 0 and after 24 hours.

induced S6RP phosphorylation in BxPC3. NT-S100A8 and TGF 11 had shared effects on mTOR, both molecules inducing $\operatorname{Ser}^{2481}$ and $\operatorname{Ser}^{2448}$ phosphorylation in all cell lines. In Capan1 S100A9 and TGF $\beta 1$ co-treatment abolished mTOR $\operatorname{Ser}^{2481}$ and $\operatorname{Ser}^{2448}$ phosphorylation induced by any of these molecules. STAT3, constitutively phosphorylated in all studied PDAC cell lines, was minimally affected by S100A8/A9 and TGF $\beta 1$ co-treatment only, which reduced in MiaPaCa2 and induced in Panc1 Stat 3 phosphorylation (Additional file 4: Figure S4).

Overall the above data indicate that the S100A8, S100A9 and S100A8/A9 heterocomplex trigger the same signaling pathways, although any molecule may evoke independent effects depending on the PDAC cell type. S100A8, S100A9 and S100A8/A9 inhibit NF-kB and Akt in PDAC cells with an intact Smad4, but not in cells (BxPC3) bearing Smad4 homozygous deletion. The independent actions of S100A8/ A9 heterocomplex and of S100A9 were particularly evident in Capan1 and Panc1 cells: like S100A8 and S100A9, S100A8/A9 inhibits NF-kB, but unlike these molecules rather than stimulating it inhibits mTOR in Capan1; conversely S100A9, unlike S100A8 and S100A8/A9, was less inhibitory on Akt in Panc1. Intriguingly, NT-S100A8 and TGF $\beta 1$ have shared effects on Akt and mTOR and, as reported for $\mathrm{S} 100$ proteins, their effects are cell type dependent: both molecules inhibited Akt $\mathrm{Thr}^{308}$, but not Akt Ser ${ }^{473}$ phosphorylation in Smad4 expressing cells (Capan1, MiaPaCa2 and Panc1) and activated mTOR in all cell lines. Finally, TGF $\beta 1$ antagonizes the effects of S100A 8 on Akt Ser ${ }^{473}$ in MiaPaCa2 and Panc1 and those of S100A9 on mTOR in Capan1, but none of the NTS100A8 effects.

\section{Smad4 deletion drives the NF-KB and Akt and reduces the mTORC1 response to $\mathrm{S100A8}$}

In order to focus on Smad4 as a potential regulator of the different effects induced by the same molecule in different cell types, we studied BxPC3, which do not express Smad4, and the stable transfected BxPC3-SMAD4+ cell line. These two cell lines were treated with all the studied molecules in the above-described conditions, and NF- $k B$, Akt, mTOR and STAT signaling were then analyzed (Additional file 5: Figure S5). Smad4 expression caused a reduced $\mathrm{I} \kappa \mathrm{B} \alpha$ phosphorylation after S100A8 treatment, and a reduced Akt $\mathrm{Thr}^{308}$ phosphorylation after S100A8/A9 treatment; these effects were not reverted by TGF $\beta 1$. When Smad4 expression was restored in BxPC3, it counteracted S100A8/A9, but not S100A8, S100A9, NT-S100A8 or TGF 31 induced mTOR Ser ${ }^{2481}$ phosphorylation. To further verify whether Smad4 impacted on the effects of S100A8, NT-S100A8 and TGF 1 on NF-kB, Akt and mTOR signaling, we analyzed $I \kappa B \alpha$, Akt, mTOR and S6RP phosphorylation in MiaPaCa2, which are Smad4 expressing cells, and in Smad4 silenced $\mathrm{MiaPaCa} 2$ (Figure 7). In agreement with the hypothesis deriving from BxPC3 and BxPC3-SMAD4+ findings that Smad4 expression permits NF- $\mathrm{B}$ inhibition, we found that Smad4 silencing reduced the inhibition of $N F-k B$ after TGF 31 and S100A8, but not after NT-S100A8 stimulation. Moreover, silenced Smad4 markedly reduced S6RP 

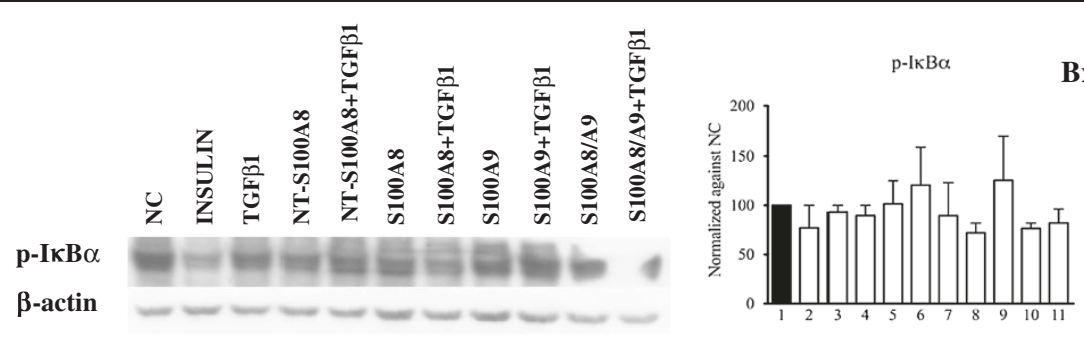

BXPC3
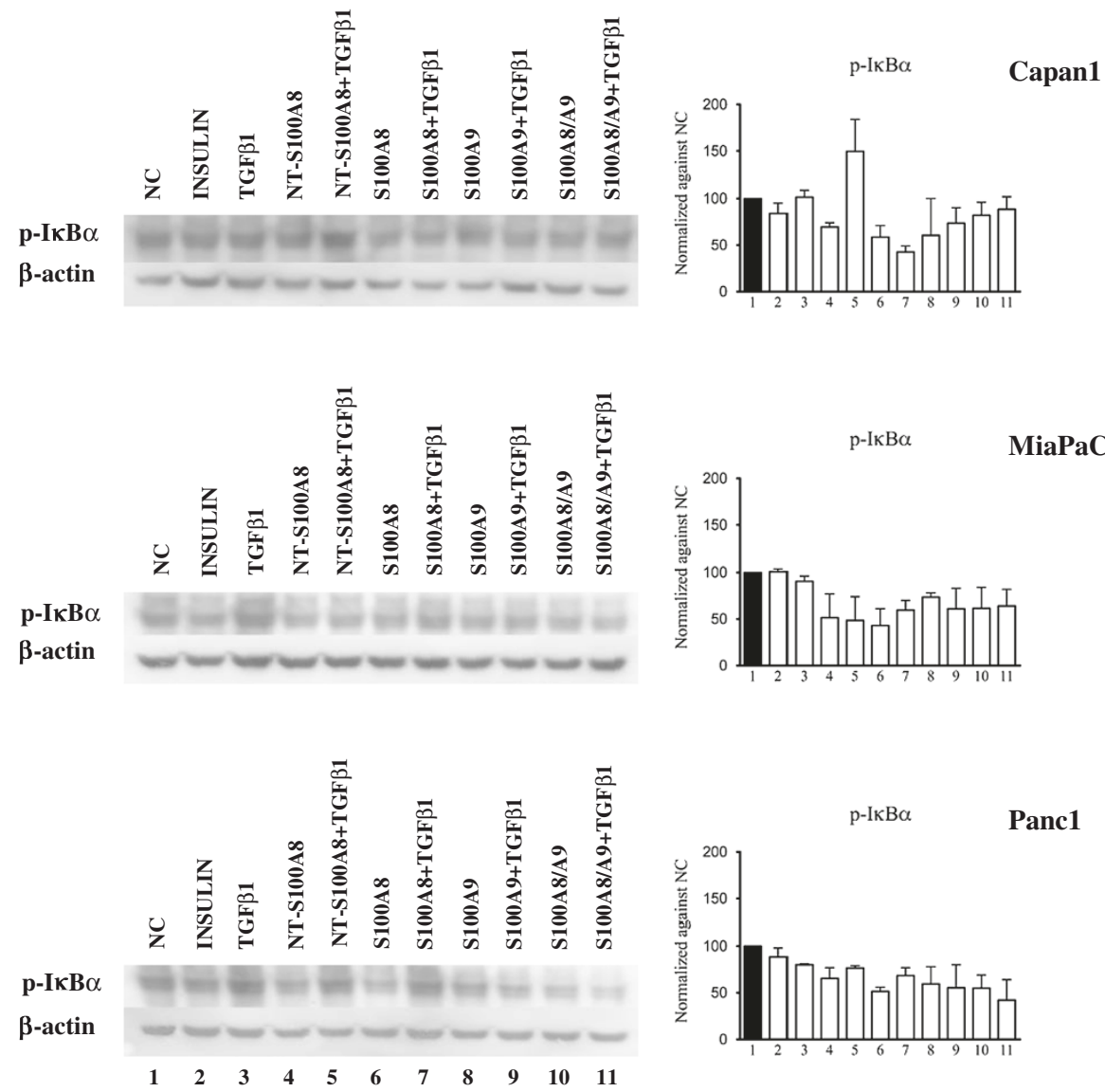

Figure 4 Differential effects of $\mathbf{S 1 0 0}$ proteins and TGF $\boldsymbol{\beta} 1$ on NF-KB signaling. BXPC3, Capan1, MiaPaCa2 and Panc1 remained unstimulated (NC, negative control) or were stimulated for 10 min with $50 \mathrm{mU}$ insulin (positive control), $0.02 \mathrm{ng} / \mathrm{ml}$ TGF $\beta 1$ alone or combined with $10 \mathrm{nM}$ S100A8, 10 nM S100A9, 10 nM S100A8/A9 complex, 50 nM NT-S100A8. Western blot show IkBa phosphorylation at Ser ${ }^{32}$ site and the corresponding $\beta$-actin, used as the control. Histograms show semi-quantification of band intensities after normalization against the negative control (O.D.; ImageJ software, $v$ 1.47). Columns indicate mean values, bars indicate SD from two independ experiments.

phosphorylation following exposure to TGF $\beta 1$, but also to S100A8 or NT-S100A8 treatment which, in Smad4 silenced cells, also induced mTOR, and reduced Akt $\mathrm{Thr}^{308}$ and Ser ${ }^{473}$ phosphorylation.

The above data indicate that Smad4 is critically involved not only in TGF $\beta 1$, but also in S100A8 and NTS100A8 signaling: these molecules preferentially activate mTOR in wild type Smad4 expressing cells, while in Smad4 negative cells S100A8 preferentially activates NF$\mathrm{KB}$ and $\mathrm{mTOR}$ while inhibiting Akt signaling.
The effects and interactions of TGF $\beta 1$ and S100 proteins in pancreatic cancer cell calcium flows

In order to ascertain whether TGF $\beta 1$ and S100 proteins affect intracellular calcium, a key ion involved in the regulation of multiple signaling pathways, the intracellular calcium concentration $\left(\left[\mathrm{Ca}^{2+}\right]_{\mathrm{i}}\right)$ was monitored for 500 seconds while Flou4 fluorescence intensity was measured in two representative PDAC cell lines, BxPC3 and $\mathrm{MiaPaCa} 2$. Figure 8 shows the BxPC3 data; each of the multiple lines in the graphs represent the $\left[\mathrm{Ca}^{2+}\right]_{\mathrm{i}}$ of one 


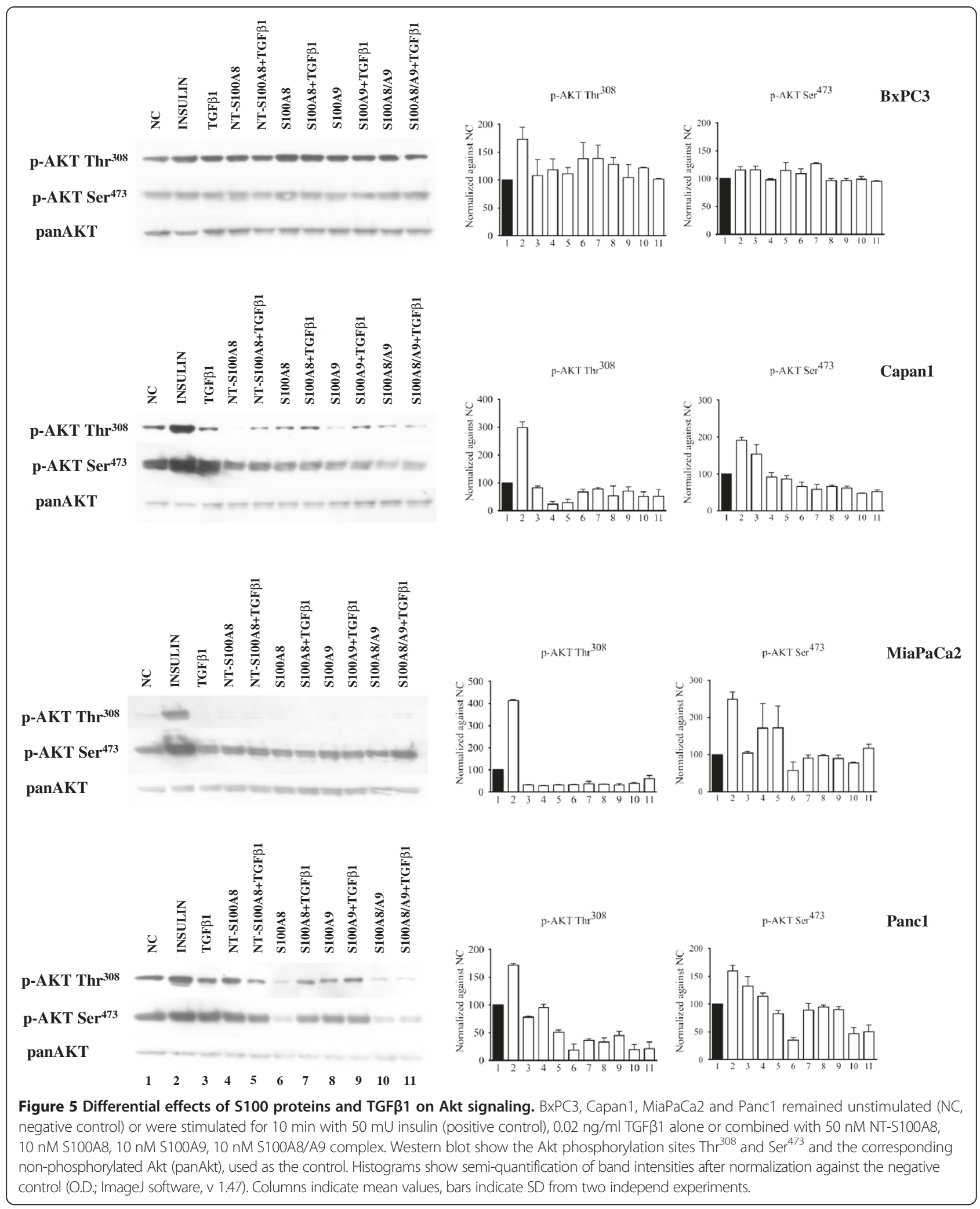

cell. Single treatment with TGF $\beta 1$, S100A8 or S100A9 did not determine evident alterations in $\left[\mathrm{Ca}^{2+}\right]_{\mathrm{i}}$, while the S100A8/A9 complex caused a cascade of $\left[\mathrm{Ca}^{2+}\right]_{\mathrm{i}}$ oscillations after 400 seconds (Figure 8I); this effect was counteracted by TGF $\beta 1$ (Figure $8 \mathrm{~L}$ ). NT-S100A8 induced $\left[\mathrm{Ca}^{2+}\right]_{\mathrm{i}}$ oscillations after 300 seconds (Figure $8 \mathrm{C}$ ); 


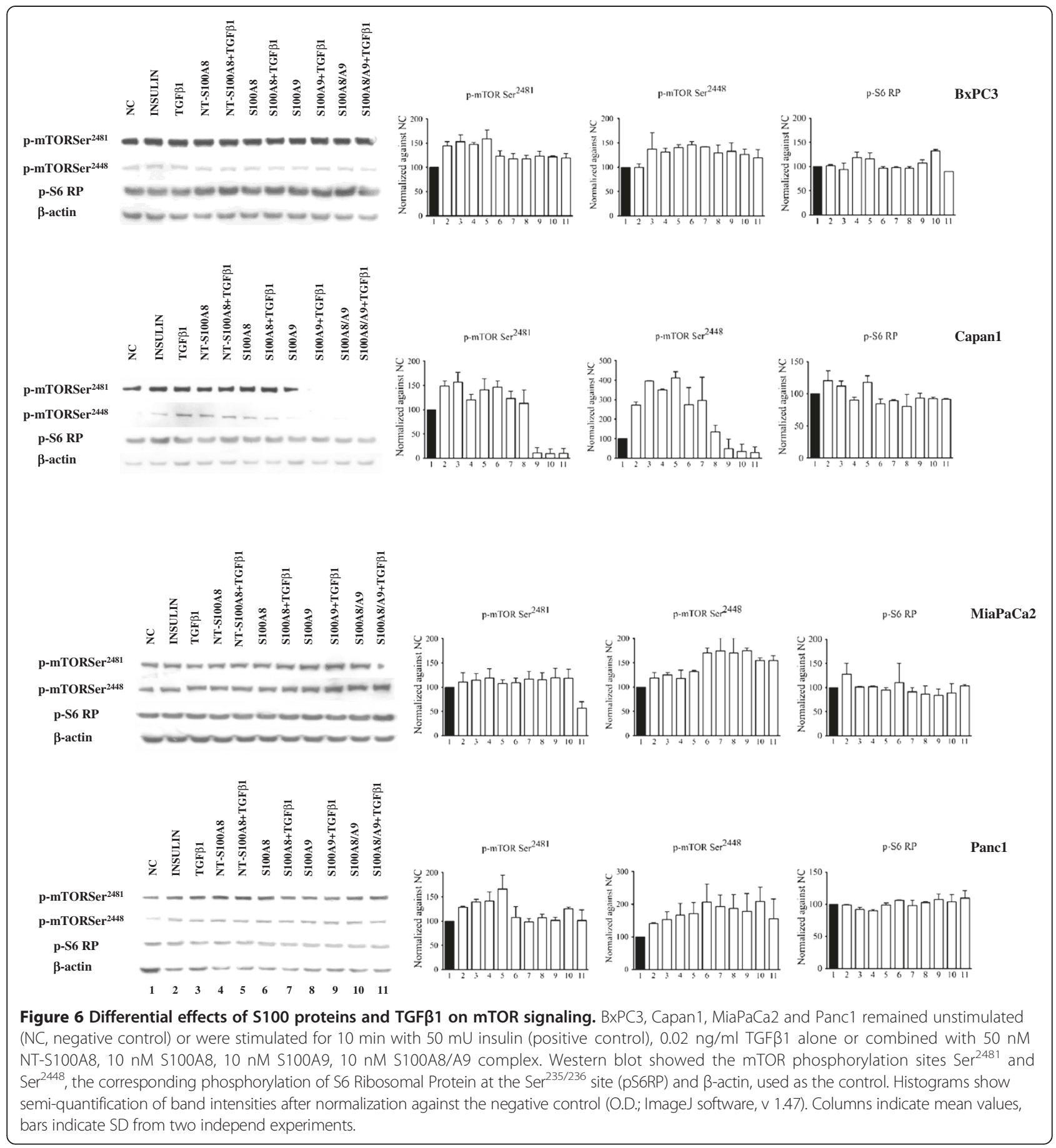

this effect was synergized and accelerated by TGF $\beta 1$ (Figure 8D). No variation in $\left[\mathrm{Ca}^{2+}\right]_{\mathrm{i}}$ was observed in the different experimental conditions investigated in Mia$\mathrm{PaCa} 2$. However, since an increasing or decreasing trend in $\left[\mathrm{Ca}^{2+}\right]_{\mathrm{i}}$ was observed in the different experimental sets, we calculated the increment or decrement in $\left[\mathrm{Ca}^{2+}\right]_{\mathrm{i}}$ per minute per cell within a 200 to 480 second interval. Figure 9 reports mean values and standard errors of the percentage variations obtained in the different experimental sets (One-Way ANOVA: $\mathrm{F}=12.17, \mathrm{p}<$ 0.0001). TGF 31, S100A8 and NT-S100A8 caused a significant decrement of $\left[\mathrm{Ca}^{2+}\right]_{i}$ with respect to control cells. The decrement induced by TGF $\beta 1$ was partly counteracted by S100A8 and S100A8/A9, and completely reverted by S100A9. These data indicate that intracellular calcium is altered by the S100A8, S100A9, S100A8/A9 heterocomplex and by NT-S100A8, these alterations being moleculeand cell type-dependent. The effects of S100A8/A9 are 

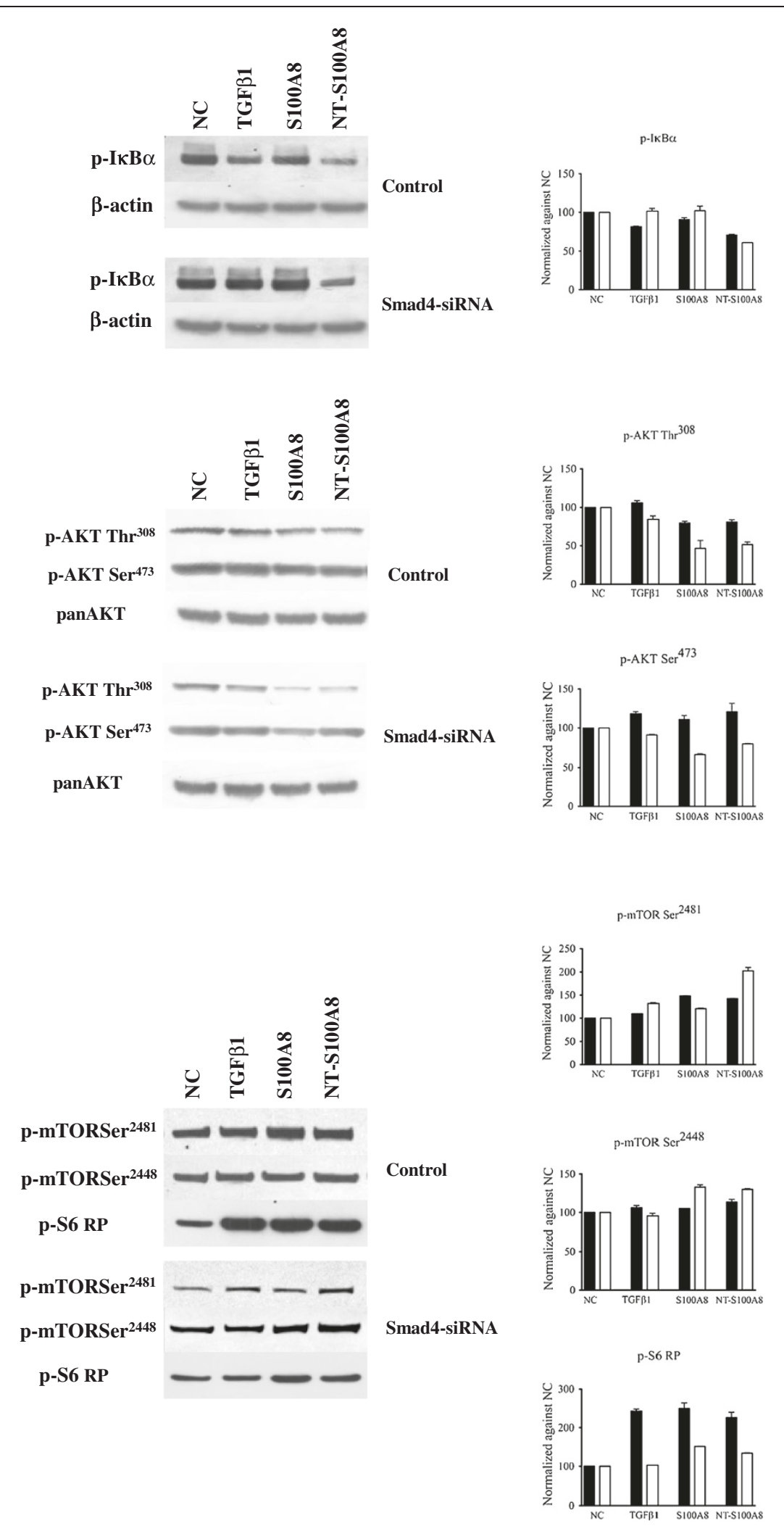

Figure 7 (See legend on next page.) 
(See figure on previous page.)

Figure 7 Effects of Smad4 deletion on NF-KB, Akt and mTOR signaling. MiaPaCa2 (Control) and Smad4 silenced MiaPaCa2 (Smad4-siRNA) remained unstimulated (NC, negative control) or were stimulated for 10 minutes with $0.02 \mathrm{ng} / \mathrm{ml}$ TGFB1, $10 \mathrm{nM}$ S100A8 or $50 \mathrm{nM}$ NT-S100A8. Upper panels show IkBa phosphorylation at $\mathrm{Ser}^{32}$ site and corresponding $\beta$-actin, used as the control. Middle panels show Akt phosphorylation sites Thr ${ }^{308}$ and Ser ${ }^{473}$ and the corresponding non-phosphorylated Akt, used as the control. Lower panels show mTOR phosphorylation sites Ser ${ }^{2481}$ and Ser ${ }^{2448}$, and the S6 Ribosomal Protein phosphorylation at $\mathrm{Ser}^{235 / 236}$ site. Histograms show semi-quantification of band intensities after normalization against the negative control (O.D.; ImageJ software, $v$ 1.47). Columns indicate mean values, bars indicate SD from two independ experiments. Black colomuns: MiaPaCa2 cells; white columns: Smad4-siRNA MiaPaCa2 cells.

antagonized by TGF $\beta 1$ and those of TGF $\beta 1$ are antagonized by S100A9; TGF 31 appears to pave the way for NTS100A8-induced alterations in intracellular calcium.

\section{TGF $\beta 1$ and S100 protein interactions and their effects on cell proliferation, EMT and apoptosis}

The proliferation of the four studied pancreatic cancer cell lines was not influenced by S100A8, S100A9, S100A8/A9 and/or TGF $\beta 1$ (Additional file 6: Table S1). Combined stimulation with NT-S100A8 and TGF $\beta 1$ induced an increase in MiaPaCa2 cell proliferation. We then verified whether proliferation was Smad4 sensitive by analyzing BxPC3 and BxPC3-SMAD4+ cell lines. As shown in Additional file 7: Figure S6, Smad4 expression was associated with a positive cell proliferation response to TGF $\beta 1$ and NT-S100A8, alone or combined, but not to the other molecules.

Since TGF $\beta 1$ is a strong promoter of the EMT, a critical step in carcinogenensis, we verified whether S100 calcium binding proteins are also involved in this process. To do this we first performed the relative quantification of Snai1, Snai2, Twist, Zeb1, Zeb2, CDH1 and $\mathrm{CDH} 2$ mRNA expression of two representative PDAC cell lines, BxPC3 and MiaPaCa2, with respect to the embryonic human cell line HEK293; the results are reported in Table 2.

EMT gene expression levels were then ascertained in BxPC3 cells treated or untreated (control) with TGF $\beta 1$, S100A8, S100A9, and the S100A8/A9 complex and NTS100A8. In BxPC3, TGF $\beta 1$ induced a 1.16 to 1.89 fold increase in all EMT genes except for Twist, which had a higher median fold increase (6.32 with respect to control cells). The relative expressions of Snai1, Snai2, Zeb1, Zeb2, CDH1 and CDH2 were not modified by S100 proteins, whereas Twist expression was significantly increased by S100A8 and by the S100A8/A9 complex to levels comparable with those of TGF $\beta 1$ (Kruskal-Wallis test: $\mathrm{p}=0.018$ ) (Figure 10A). The effects of TGF $\beta 1$, S100A 8 and S100A8/A9 on Twist expression were much less evident when these molecules were simultaneously added to the cell cultures (Figure 10A). These findings were confirmed by those made at immunocytochemistry (Figure 10B). The E-cadherin protein was not expressed by untreated or treated BxPC3 cells. The findings for $\mathrm{N}-$ cadherin are shown in Additional file 8: Figure S7.
Untreated cells showed dishomogeneous non-continuous membranous $\mathrm{N}$-Cadherin immunostaining whereas TGF 1 1, S100A8, S100A9 and NT-S100A8 immunostaining was less marked than in control cells. The S100A8/ A9 complex caused enforced moderate to complete membranous immunostaining. When cells were costimulated with TGF $\beta 1$ and S100A8 or S100A9, weak complete immunostaining was observed. These data confirm that TGF $\beta 1$ is an EMT inducer and that Twist is its main target gene. Twist expression may also be enhanced by $\mathrm{S} 100$ calcium binding proteins but also by NT-S100A8. The effects of TGF $\beta 1$, S100A8 and S100A9 on EMT are mutually antagonistic when these molecules are added together.

To examine whether the studied molecules have proapoptotic effects on PDAC cells, cleaved caspase-3 was analyzed by western blot; this $17 \mathrm{kDa}$ fragment was hardly detected (detectable only in fragments) in both control and treated Capan1, MiaPaCa2 and Panc1 cells. Cleaved caspase-3, present in BxPC3, was unaffected by any of the treatments (Figure 10C).

\section{TGF $\beta 1$ and S100 proteins interact and form heterocomplexes}

In order to verify whether S100A8, S100A9 and TGF 31 interact each other at a molecular level, these molecules were mixed at a 1:1 molar ratio in the presence of $\mathrm{Ca}^{2+}$, incubated overnight at room temperature and then analyzed by MALDI-TOF/MS. S100A8 formed homo-dimers, while S100A9 and TGF $\beta 1$ formed homo-dimers and homotrimers. S100A8 and S100A9 formed hetero-dimers not only between themselves, but also with TGF $\beta 1$ (Figure 11). MALDI-TOF/MS findings were confirmed by co-immununoprecipitation experiments: TGF $\beta 1$ was detected in the fraction of polypeptides eluted from S100A8- and S100A9Sepharose (Figure 11E and F, respectively). These data clearly indicate that TGF $\beta 1$, S100A8 and S100A9 are partner molecules.

\section{Discussion}

The levels of calcium binding proteins S100A8 and S100A9 increase in cancer, including PDAC; although mainly expressed by tumor-infiltrating inflammatory cells, they may also be expressed by PDAC cells [31,34]. These proteins are directly involved in piloting metastases by the 

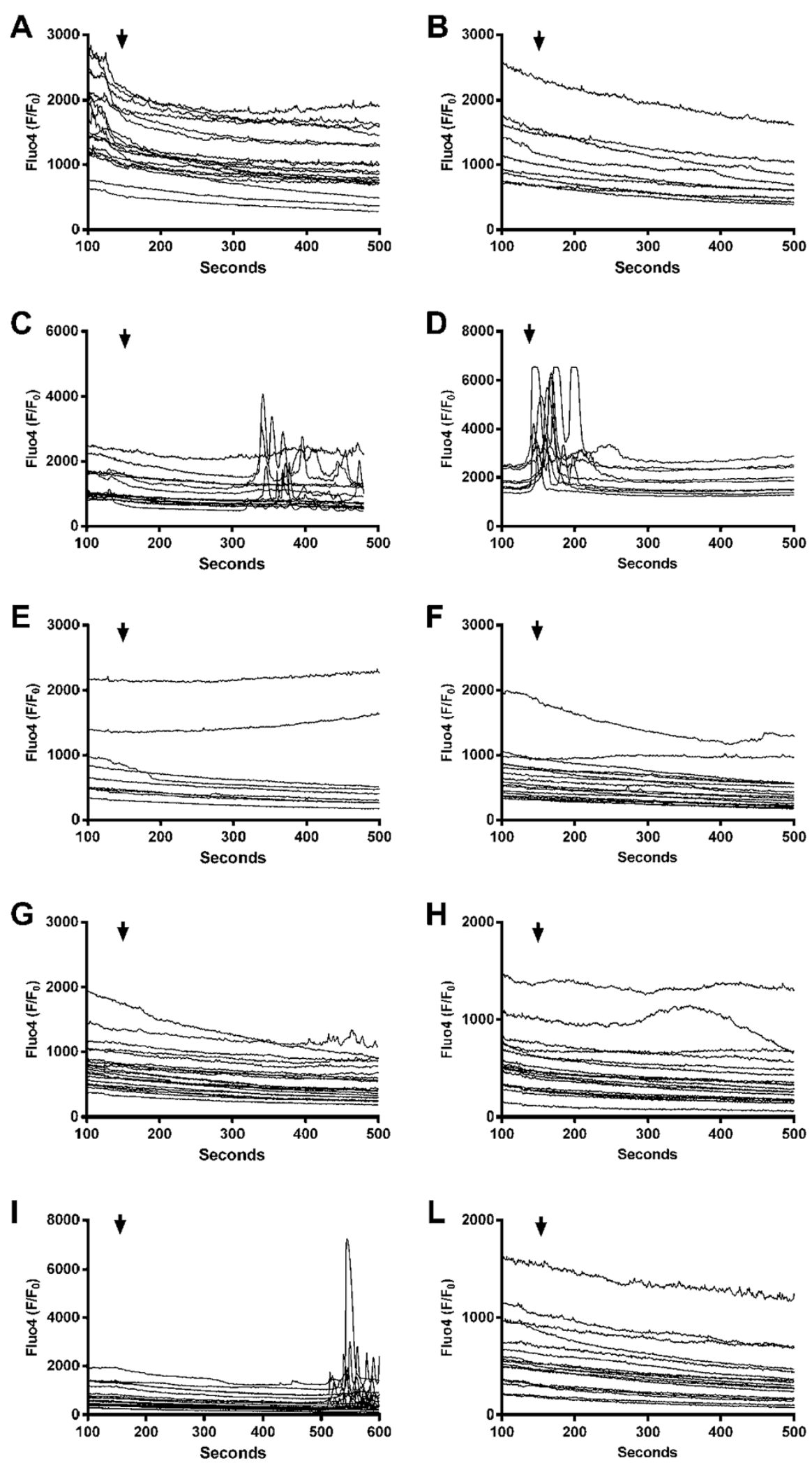

Figure 8 Intracellular calcium concentration $\left(\left[\mathrm{Ca}^{2+}\right]_{i}\right)$ in BxPC3 cells. $\left[\mathrm{Ca}^{2+}\right]_{i}$ was monitored for 500 seconds by epifluorescence after stimuli (arrows). Each of the multiple lines in the graphs represent the $\left[\mathrm{Ca}^{2+}\right]_{\mathrm{i}}$ of one cell. A: Control; B: TGF $\beta 1 ;$ C: NT-S100A8; D: NT-S100A8 plus TGF $\beta 1$; E: S100A8; F: S100A8 plus TGFß1; G: S100A9; H: S100A9 plus TGFB1; I: S100A8/A9; L: S100A8/A9 plus TGFß1. 


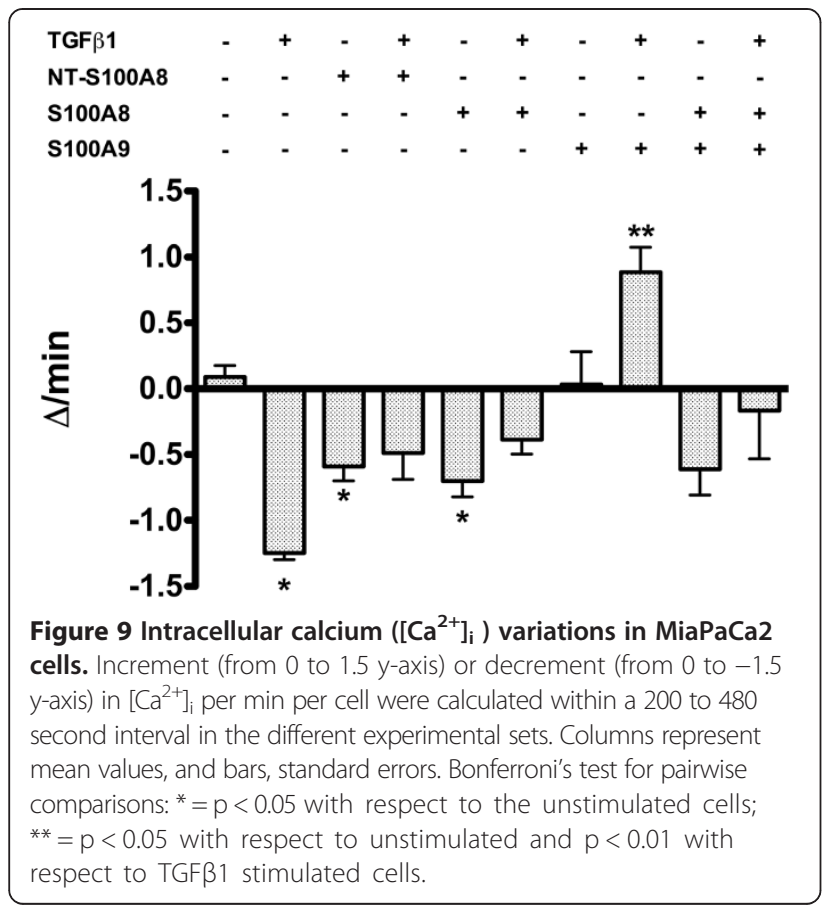

ligation of TLR4 and RAGE receptors [29,30,44]. The latter receptor, critical to bridging inflammation and cancer [45], and its ligation, initiates a feed-forward loop that potentiates inflammation, but may also favor the oncogenic switch $[24,30]$. In agreement with the hypothesis that S100A8 and S100A9 have a potential metastatic role, S100A8 and S100A9 mRNA levels were almost undetectable in the primary BxPC3, MiaPaCa2 and Panc1, while they were highly expressed by the metastatic SUIT2 and Capan1 PDAC cell lines [46]. Further supporting the potential role of S100A8/A9 proteins in metatases, high expression of their receptor, RAGE, was present not only in metastatic Capan1, but also in the primary MiaPaCa2 cells, which cause a liver metastases rate overlapping that of Capan1 [47]. The other S100A8/A9 receptor, TLR4 [29], is reported to activate STAT3 [48]. The finding that this signal transducer was constitutively activated in all

Table 2 EMT genes mRNA relative quantification in the studied pancreatic cancer cell lines

\begin{tabular}{|c|c|c|c|}
\hline & $\mathrm{BxPC3}$ & MiaPaCa2 & Hek293 \\
\hline & Fold increase & Fold increase & Reference \\
\hline Snai1 & 0.04 & 0.74 & 1 \\
\hline Snai2 & 0.11 & 2.06 & 1 \\
\hline Twist & $0.48 \times 10-3$ & $0.38 \times 10-3$ & 1 \\
\hline Zeb1 & 0.12 & 0.32 & 1 \\
\hline Zeb2 & $0.87 \times 10-3$ & Absent & 1 \\
\hline $\mathrm{CDH} 1$ & 0.03 & $4.07 \times 10-3$ & 1 \\
\hline $\mathrm{CDH} 2$ & 0.04 & Absent & 1 \\
\hline
\end{tabular}

A

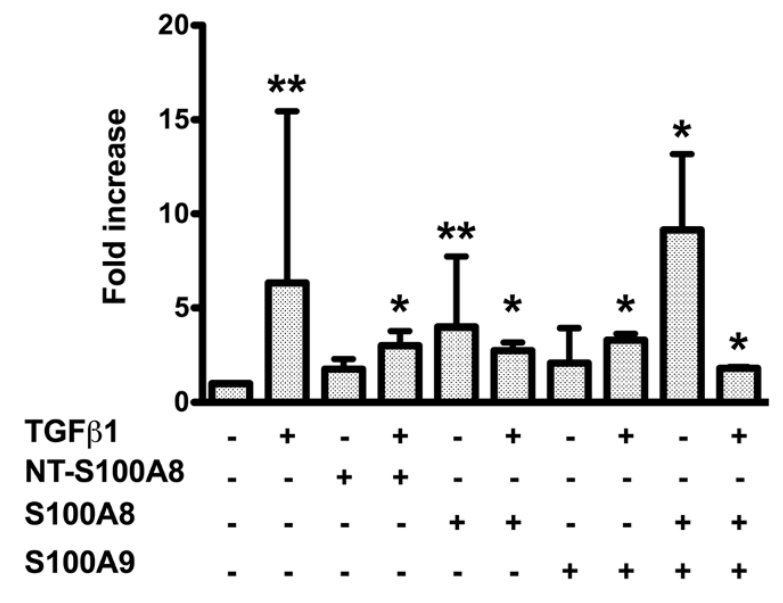

B

Twist immunostain

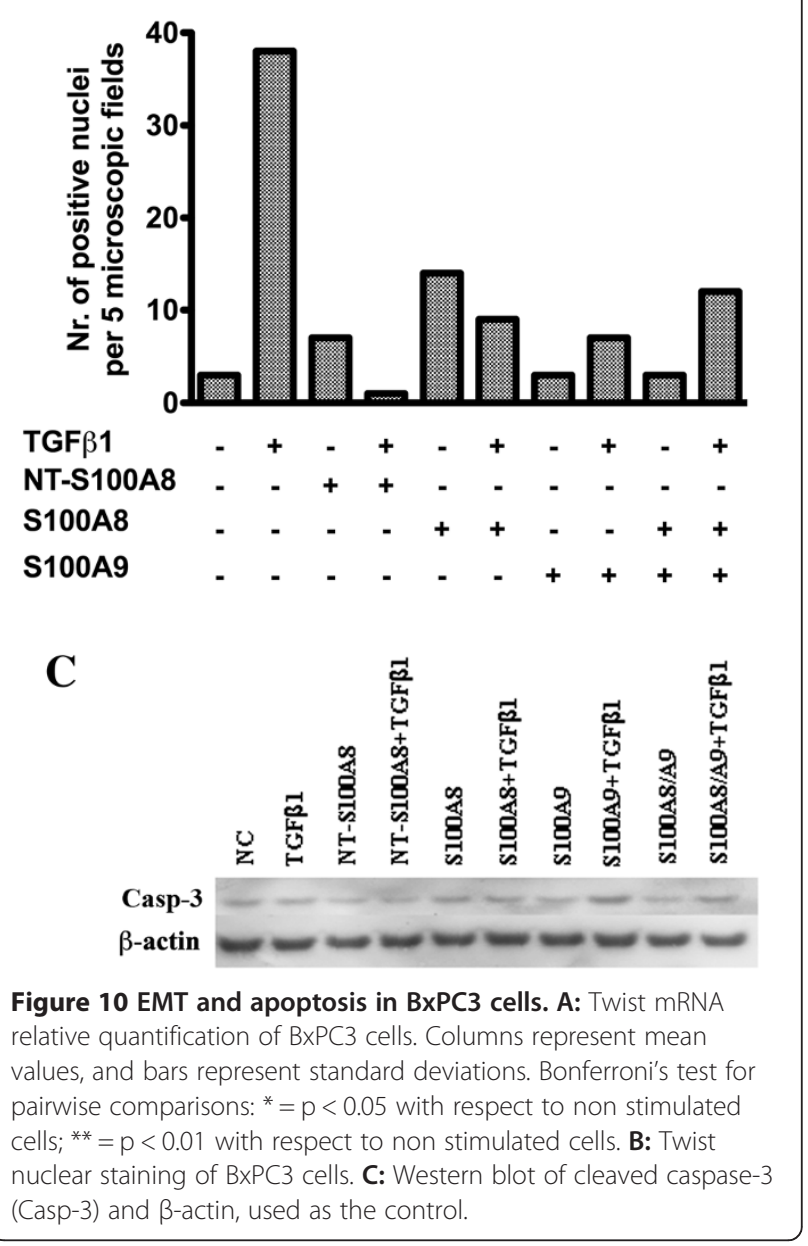

PDAC cell lines, supports the hypothesis that it plays role in this cancer type [49]; however the fact that it was not induced by the S100 studied molecules, suggests that they act mainly through RAGE engagement. 


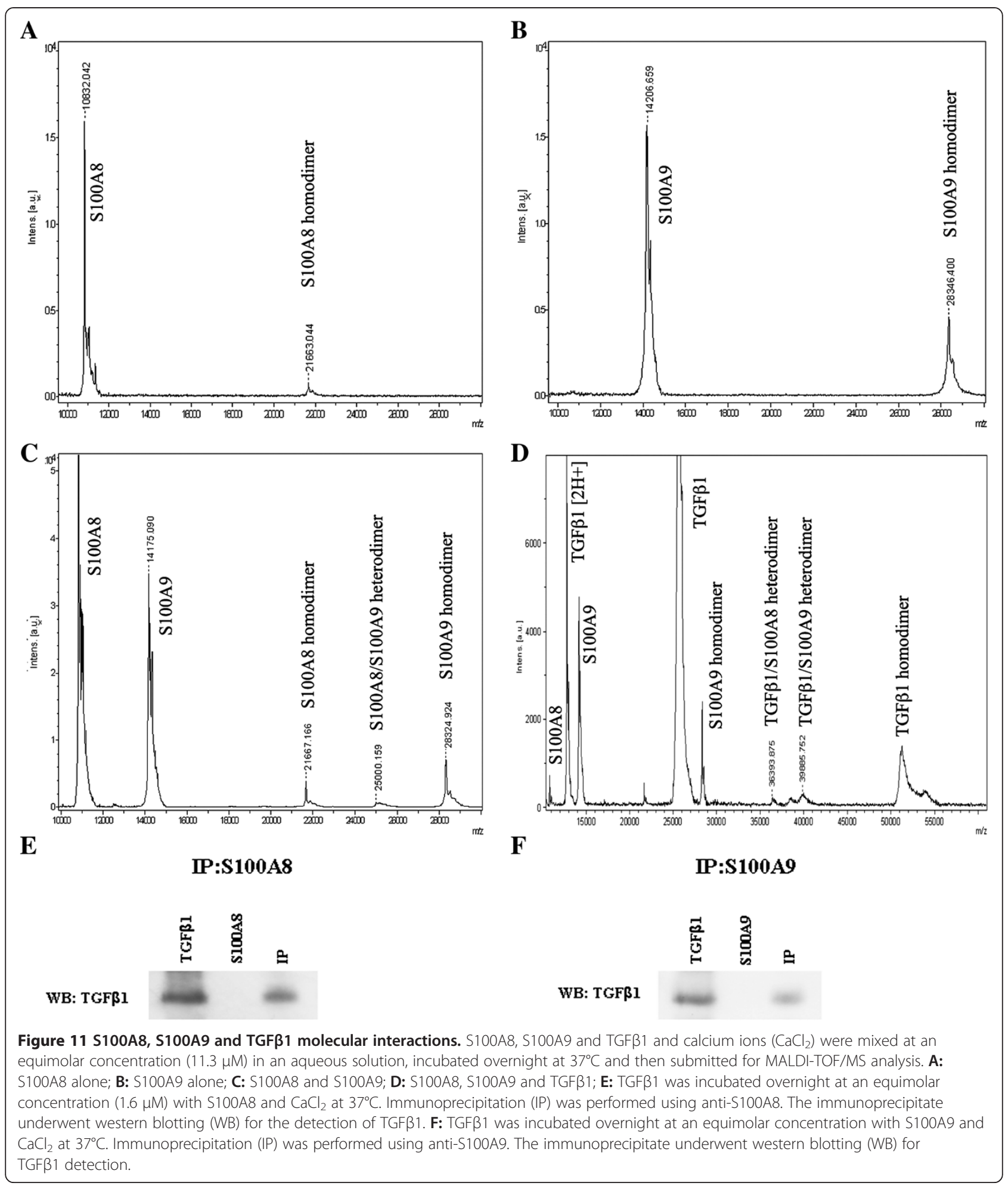

In a previous study we demonstrated that PDAC tissue is enriched by the biologically active $\mathrm{N}$-terminal 14 aa fragment of S100A8 (NT-S100A8) [34]. In this study, in order to further exploit tumor stoma interactions, we first verified whether tumor cells release soluble mediators able to fragment the S100A8 protein. Since the 12-15 aminoacid sequence IIDV of S100A8 fits with the group II consensus motif (L/IXX | XHy) of MMP2 [50], we ascertained whether MMPs have a role in causing the release of NT-S100A8. In the presence of PDAC - 
derived products, S100A8 resulted in a series of low molecular weight peptides, which were more abundant at $2280 \mathrm{~m} / \mathrm{z}$. At MS/MS analysis, the $2280 \mathrm{~m} / \mathrm{z}$ peptide was found to correspond to the N-terminal 19 aa sequences of the original S100A8 protein, this being five aa longer than the PDAC-associated NT-S100A8 peptide [34]. The assumption that PDAC-derived MMPs might be responsible for S100A8 fragmentation and delivery of the $2280 \mathrm{~m} / \mathrm{z}$ peptide was supported by the finding that S100A8 was not fragmented by conditioned media obtained from cells treated with Ukrain, which downregulates the activities of MMPs [41]. In the presence of PDAC cell conditioned media, the $2280 \mathrm{~m} / \mathrm{z}$ peptide was resolved in two main degradation products at 1435 and $1030 \mathrm{~m} / \mathrm{z}$, which encompass the 8-19 and the 2-10 S100A8 aminoacid sequence, but also in a fragment at $1852 \mathrm{~m} / \mathrm{z}$, encompassing the 1-16 N-terminal aminoacid sequence of S100A8, which is very close to the NTS100A8. This peptide was also detected when the entire S100A8 was incubated with Capan1 conditioned media, thus confirming that it derives from PDAC induced proteolytic cleavage of this calcium binding protein. Both BxPC3 and Capan 1 conditioned media equally processed the $2280 \mathrm{~m} / \mathrm{z}$ peptide, but the kinetics were different: metastatic Capan1 cells caused a more rapid (2 hours) degradation of the parental $2280 \mathrm{~m} / \mathrm{z}$ peptide than the poorly metastatic BxPC3 cells (12 hours), and this indicates that PDAC cells, depending on their metastatic potential, produce different amounts of the same S100A8 targeting proteases. PDAC-associated S100A8 degradation may be governed by a regulatory mechanism restricting its function, but the release of peptides with their own biological activity might circumvent this phenomenon and modify tumor biology. We therefore studied the effects of S100A8, S100A9 and the S100A8/ A9 complex, but also of NT-S100A8, on critical aspects of tumor biology, namely intracellular signaling, cell proliferation and EMT. On investigating NF- $\mathrm{kB}$, Akt and mTOR signaling, we found that all these signaling pathways are differently targeted by S100A8, S100A9 and NT-S100A8 depending on the PDAC cell type (results summarized in Additional file 9: Figure S8). In PDAC cells with intact Smad4 (Capan1, MiaPaCa2 and Panc1), S100A8, S100A9 and S100A8/A9 shared an overall inhibitory effect on NF- $\mathrm{B}$, while these molecules did not affect NF- $\kappa B$ in the presence of SMAD4 homozygous deletion (BxPC3 cells). It has recently been suggested that NF- $\mathrm{kB}$ activation in PDAC is closely involved in driving tumor progression, especially when its activation is sustained, and that it plays a key role in linking inflammation and cancer [51]. Our findings suggest that S100 proteins, by targeting NF- $\mathrm{kB}$ signaling, may counteract cancer progression in Smad4 positive, but not in Smad4 negative, PDAC. However, other intracellular pathways, such as Akt, are critically involved in cancer proliferation, angiogenesis and metastases [43]. The two Akt activation sites, $\mathrm{Thr}^{308}$ and $\mathrm{Ser}^{473}$, were dephosphorylated by S100A8, S100A9 and S100A8/A9 in Smad4 expressing cells, while Akt $\mathrm{Thr}^{308}$ was activated and $\mathrm{Ser}^{473}$ unaffected by all these molecules in Smad4 negative BxPC3 cells.

Overall, the above data suggest that Smad4 deletion is permissive for S100A8/A9 activation of NF-kB and Akt signaling pathways in PDAC cells. Interestingly, NTS100A8 was far from ineffective and had effects similar to those of its parent molecule S100A8: the phosphorylation grade of the Akt $\mathrm{Thr}^{308}$ site was induced in BxPC3, and reduced in Capan 1 and MiaPaCa2. In the PDAC setting, therefore, the degradation of S100A8 does not abolish its biological effects on PDAC cells, its NT-S100A8 proteolytic fragment maintaining them.

Akt signaling depends on a complex relationship with mTOR signaling: Akt activates mTOR complex 1 (mTORC1), while mTORC2 phosphorylate Akt on the hydrophobic motif $\mathrm{Ser}^{473}$ [43]. However, in human PDAC, mTOR phosphorylation was more closely associated with cancer cells than Akt phosphorylation, which was found in the neoplastic ducts, but also in acinar, islet and stroma cells [52]. We therefore ascertained whether S100 proteins affected mTOR. As the catalytic subunit of the two distinct complexes, mTORC1 and mTORC2 [53], mTOR was sensitive to S100A8, which induced in BxPC3, Capan1 and MiaPaCa2 Ser ${ }^{2481}$ phosphorylation. Interestingly, the S100A9, but above all the S100A8/A9 complex, have opposite effects on mTOR: they induced mTOR phosphorylation in BxPC3, Mia$\mathrm{PaCa} 2$ and Panc1 and reduced it in Capan1. NT-S100A8 induced mTOR Ser ${ }^{2481}$, but also $\mathrm{Ser}^{2448}$ phosphorylation in almost all PDAC cell lines. Overall, our findings support the hypothesis that S100A8, S100A9 and NTS100A8 are Janus-faced molecules [28] that can have pro- and anti-cancer effects, depending on the cellular context. Since the four cell lines studied differ in their differentiation grade but also have distinct genetic aberrations, Smad4 in particular [42,54], our hypothesis was that opposite responses to the same S100 molecule in different cell lines might depend on Smad4 status. To verify this, we selected cell without (BxPC3) and with (MiaPaCa2) Smad4 expression. BxPC3 were compared with BxPC3-SMAD4+ cells and MiaPaCa2 were compared with Smad4-siRNA-transfected MiaPaCa2 cells. Our findings confirmed that S100A8 does not inhibit or even activate NF- $\mathrm{kB}$ in the absence of Smad4 expression, but also supported the observation that S100A8 and NT-S100A8 activate mTOR independently from Smad4 status. Since Smad4 is critically involved in TGF $\beta 1$ signaling, it is reasonable to assume that there is a close link between these calcium binding proteins and TGF $\beta 1$ 
in pancreatic cancer. Therefore we also studied the combined effects of TGF $\beta 1$ and S100A8, S100A9, S100A8/ A9 and NT-S100A8. TGF $\beta 1$ partly counteracted the effects of S100 proteins on NF-kB and Akt signaling in cells with Smad4 expression, but not those on mTOR. The effects of NT-S100A8 on Akt and mTOR, not those on NF-kB, were very similar to those exerted by S100A8, but were almost completely equal to those of TGF $\beta 1$ thus suggesting that NT-S100A8 might be functionally considered a TGF $\beta 1$-like molecule. The functional similarity between NT-S100A8 and TGF $\beta 1$ was also found when their effects on cell growth were evaluated. These two molecules synergistically stimulated the growth of MiaPaCa2 cells, but also the growth of BxPC3-SMAD4+, not that of BxPC3 cells, suggesting that this synergistic pro-proliferative effect is Smad4 dependent.

S100A8, S100A9, NT-S100A8 and TGF $\beta 1$ interactions were also found on intracellular calcium, which was analyzed because a crosstalk between calcium signaling and proliferation pathways has been well documented $[35,37,38,55]$. TGF $\beta 1$ accelerated the rapid train of intracellular calcium oscillations evoked by NT-S100A8 in BxPC3; this further supports the notion that these two molecules share effects and act in co-operation. Like NT-S100A8, the heterocomplex S100A8/A9, not any single molecule, evoked a sequence of intracellular calcium oscillations but, in the latter case, TGF $\beta 1$ counteracted the observed effect rather than reinforcing it. In MiaPaCa2, NT-S100A8 and S100A8 caused a reduction in intracellular calcium, and TGF $\beta 1$ had a similar effect. Importantly, S100A9 reversed the effects of TGF $\beta 1$, this finding further supporting the hypothesis that interactions may occur between TGF $\beta 1$ and S100 proteins.

In view of the interactions between $\mathrm{S} 100$ proteins and TGF $\beta 1$, and the fact that TGF $\beta 1$ is a well known inducer of EMT, a relevant biological phenomenon in morphogenesis and in cancer initiation and progression, we ascertained whether the observed molecular interactions also occur in this process. Of the two cell lines studied, the less differentiated and more aggressive $\mathrm{MiaPaCa} 2$ cell line expressed EMT genes at a level comparable to that of embryonic cells, suggesting a pre-existent EMT process. We therefore studied the more differentiated BxPC3 cells that, unlike the other cell lines, constitutively expressed cleaved caspase-3. However, none of the molecules studied induced this apoptotic marker. TGF $\beta 1$, as expected, induced an increased expression of all the EMT markers studied, while the S100 proteins induced only Twist mRNA expression, although in a different manner. The main inducers were the S100A8 and the S100A8/A9 complex, and these findings were confirmed at immunocytochemistry.

Since it has been claimed that Twist is involved not only in EMT, but also in inhibiting p53 mediated apoptosis, in the acquired resistance of cancer cells to chemotherapy and in circumventing oncogenic $k$-ras mediated cellular senescence [56,57], our results further indicate a link between the inflammatory S100 molecules and cancer progression. The effects of TGF $\beta 1$ and S100A8 on Twist expression were not cumulative, being reduced when both substances were added together, and S100A9, once again, counteracted the effects of TGF $\beta 1$. Interestingly, TGF $\beta 1$, but also S100A9 and NT-S100A8 reduced the membrane expression of $\mathrm{N}$-Cadherin, while these effects were less pronounced when cells were costimulated with TGF $\beta 1$ and S100A9 or NT-S100A8.

All the above-described functional interactions may be due to different factors, including the sharing of coreceptors, and receptor interactions, but they might also be due to complex interactions between S100A8/A9 proteins and other molecules, like those occurring between S100A4 and amphiregulin [58] or S100B and basic fibroblast growth factor $[59,60]$. These interactions might prevent the canonical RAGE engagement by S100A8/A9 and enhance signaling of other receptors, like those of the interacting molecules, as demonstrated to occur when S100B interacts with $\beta F G F$ [60]. We demonstrated by MALDI-TOF/MS and co-immunoprecipitation that TGF $\beta 1$ not only forms homo-dimers, but also homo-trimers and that this is true also for S100A9 (not shown), while S100A8 appears to almost exclusively form homo-dimers. It was confirmed that S100A8 and S100A9 form hetero-dimers but, as hypothesized, TGF $\beta 1$ was able to form hetero-complexes with both S100 molecules. In vivo, these interactions, occurring at the tumor stroma interface, probably contribute in the balance between the reported pro- and anti-tumor effects of S100A8/A9 in PDAC and further investigations of this phenomenon might allow the identification of new potential targets for intervention.

\section{Conclusions}

In this study we demonstrated that in the PDAC setting important interactions occur between the calcium binding proteins S100A8 and S100A9 and TGF $\beta 1$. PDAC cells derived proteases target the inflammatory S100A8 protein causing the release of small peptides. One of these peptides, NT-S100A8, is biologically active and was demonstrated to exert TGF $\beta 1$-like effects on PDAC cell NF-kB, Akt and mTOR signaling and to synergize with TGF $\beta 1$ in altering intracellular calcium and in stimulating cell proliferation. Smad4 status affects S100A8 signaling, favoring mTORC1 when expressed and NF-kB when deleted. S100A9, by binding TGF $\beta 1$, counteracts the effects of this molecule on intracellular calcium, signaling and the EMT process.

\section{Materials and methods \\ Cell lines}

The pancreatic cancer cell lines used were: Panc1 and Suit2, donated by Prof Aldo Scarpa (University of 
Verona, Italy); BxPC3, from Dr Andrea Galli (University of Florence, Italy); MiaPaCa2, Capan1 and the human embryonic kidney Hek293 cell lines, supplied by the American Type Culture Collection (Manassas, VA, USA). BxPC3, Capan1 and Panc1 were cultured in RPMI (Gibco/BRL, Gaithhersburg, MD, USA) supplemented with 10\% (BxPC3 and Panc1) and 20\% (Capan1) fetal calf serum (FCS) (Gibco/BRL), 1\% L-glutamine (Gibco/BRL) and 0.1\% gentamycin (Gibco/BRL). MiaPaCa2 and Hek293 were cultured in DMEM (Gibco/BRL) supplemented with 10\% FCS, $2 \%$ Lglutamine and $0.1 \%$ Gentamycin. BxPC3 cells were transfected with the expression vector pBK-cytomegalovirus (CMV)-SMAD4/DPC4, as previously described [34]. One SMAD4/DPC4-expressing clone (BxPC3-SMAD4+) was used for the experiments. Smad4 silencing of MiaPaCa2 cells was performed as previously described [61].

\section{Culture media for S100A8 proteolysis assay}

To obtain BxPC3 and Capan1 conditioned media (CM), 400,000 cells were cultured ( $75 \mathrm{~cm}^{2}$ flasks) for 96 hours in RPMI supplemented with $1 \%$ FCS and $0.1 \%$ gentamycin. In parallel, Ukrain (Nowicky Pharma, Wien, Austria) treated Capan1 CM were obtained as above, the difference being that Ukrain was added 24 hours after cells had been seeded at the final concentration of $5 \mu \mathrm{M}$. Complete culture media maintained in a cell culture incubator for 96 hours (negative control), Capan1 and Ukrain-treated Capan1 CM were centrifuged at $1,500 \mathrm{rpm}$ for $10 \mathrm{~min}$, and then immediately mixed with $3 \mu \mathrm{M}$ S100A8 or $2.5 \mu \mathrm{M}$ S100A9 (ProSpec-Tany TechnoGene, Ness Ziona, Israel) and maintained at $37^{\circ} \mathrm{C}$ overnight before MALDITOF/MS analyses. Complete culture media, BxPC3 and Capan1 CM, treated as described above, were incubated at $37^{\circ} \mathrm{C}$ with $200 \mu \mathrm{M}$ of the S100A8 1-19 N-terminal aminoacid sequence (NT-S100A8) (Primm, Milano, Italy) for 1, 2, 3, 4, 5, 6, 12 and 24 hours before MALDI-TOF/MS analyses. At least three independent sets of experiments were performed for both assays.

\section{Sample preparation for immunoblot analysis}

Five million cells were seeded in Petri dishes $(\varnothing 10 \mathrm{~cm})$ and cultured for 24 hours in their respective complete media prior to starting the experiments. Cells remained non-stimulated (negative control) or were stimulated with $50 \mathrm{mU}$ insulin (positive control) (Insuman Rapid, Sanofi-Aventis, Deutschland, $\mathrm{GmbH}$ ) for $10 \mathrm{~min}$; in parallel, experimental cells were stimulated with $50 \mathrm{nM}$ NT-S100A8, 0,02 ng/ml TGF $\beta 1$ (ProSpec-Tany TechnoGene), $10 \mathrm{nM} \mathrm{S100A8}$ and $10 \mathrm{nM}$ S100A9 alone or combined for $10 \mathrm{~min}$. Following stimulations, Petri dishes were immediately transferred into an ice bath, and the cells were washed twice with cold PBS, resuspended in $100 \mu \mathrm{l}$ of cold lysis buffer [20 mM Tris$\mathrm{HCl}, \mathrm{pH}$ 7.5, 150 mM NaCl, 1 mM EDTA, 1\% Triton-X
100, $50 \mathrm{mM} \mathrm{NaF}, 10 \mathrm{mM} \mathrm{Na} \mathrm{m}_{2} \mathrm{O}_{7}, 1 \mathrm{mM} \mathrm{Na} \mathrm{VO}_{4}$, and $10 \%$ protease inhibitor cocktail (Sigma Aldrich SRL, Milano, Italy)]. Lysates were centrifuged for $10 \mathrm{~min}$ at $14,000 \mathrm{rpm}$ at $4^{\circ} \mathrm{C}$ and, in the supernatants, total proteins were measured using the Bio-Rad protein assay (Bio-Rad Laboratories, Milano, Italy). Each experiment was performed at least in triplicate.

\section{Immunoblot analysis and co-immunoprecipitation}

For each sample, $40 \mu \mathrm{g}$ proteins were electrophoresed through 4-12\% NuPAGE ${ }^{\oplus}$ NovexBis-Tris SDS-PAGE Gel or $3-8 \%$ NuPAGE ${ }^{\oplus}$ NovexTris-Acetate SDS-PAGE Gel (Invitrogen S.R.L., Life Technologies, Monza, Italy) and electrophoretically transferred to Nitrocellulose Membrane (iBlot ${ }^{\oplus}$ Transfer Stack, Invitrogen S.R.L.) by means of the iBlotTMDry Blotting System (Invitrogen S.R.L.). Following incubation for 1 hour in a blocking buffer [5\% low fat powder milk re-suspended in PBS-T (PBS with $0.1 \%$ Tween-20)], membranes were incubated overnight at $4^{\circ} \mathrm{C}$ with the primary antibodies [antiphospho IkB- $\alpha$ $\left(\mathrm{Ser}^{32}\right.$ ) (Santa Cruz Biotechnology, Inc., Santa Cruz, CA, USA); anti-phospho-Akt (Ser ${ }^{473}$, anti-phospho-Akt $\left(\mathrm{Thr}^{308}\right)$, anti-Akt and anti-phospho-S6 Ribosomal Protein $\left(\mathrm{Ser}^{235 / 236}\right)$, anti-cleaved Caspase-3, anti-phosphoStat3 $\mathrm{Tyr}^{705}$, anti- $\beta$-actin, anti-phospho mTOR (Ser ${ }^{2448}$, Ser $^{2481}$ ) (Cell Signaling Technology, Danvers, MA, USA); anti-RAGE (R\&D Systems, Minneapolis, MN, USA) ] diluted 1:5000 ( $\beta$-actin), 1:2000 (mTOR, cleaved Caspase-3, Stat3) or 1:3000 (all the others) in the blocking buffer. The blots, washed three times in PBS-T for 15 min, were incubated with alkaline phosphatase-conjugated anti-rabbit (Cell Signaling Technology) or anti-goat (Sigma Aldrich) secondary antibodies and then washed three times in PBS-T for $15 \mathrm{~min}$ and developed with the ECL Advance Western Blot Detection Kit (GE Healthcare Technologies, Milan, Italy).

Co-immunoprecipitation experiments were performed using protein G-Sepharose (GE Healthcare Technologies). TGF $\beta 1(1.6 \mu \mathrm{M})$ was incubated in equimolar concentrations with $\mathrm{S} 100 \mathrm{~A} 8$ or $\mathrm{S} 100 \mathrm{~A} 9$ at $37^{\circ} \mathrm{C}$ overnight in the presence of equimolar $\mathrm{CaCl}_{2}$. The mixtures were then incubated for $2 \mathrm{~h}$ with anti-S100A8 polyclonal or anti-S100A9 monoclonal antibodies (Santa Cruz Biotechnology) preadsorbed to protein G. Immunoprecipitates, washed three times in $10 \mathrm{mM}$ Tris $\mathrm{HCl}$ containing $40 \mathrm{mM} \mathrm{NaCl}, \mathrm{pH} 7.5$, were boiled in an SDS-PAGE sample buffer before electrophoresis on $4-12 \%$ NuPAGE ${ }^{\circledR}$ NovexBis-Tris SDS-PAGE gels. After protein transfer, nitrocellulose membranes were blotted with antiTGF $\beta 1$ antibody (Cell Signaling Technology).

\section{Effects of S100A8, S100A9, NT-S100A8 and TGF $\beta 1$ on $\mathrm{BxPC} 3$ and MiaPaCa2 intracellular calcium $\left(\left[\mathrm{Ca}^{2+}\right]_{\mathrm{i}}\right)$} BxPC3 and MiaPaCa2 cells, seeded $\left(80 \times 10^{3}\right.$ cells $)$ on coverslips that had been inserted within each well of six 
well culture plates, were kept in their respective complete media for 24 hours. Coverslips were then incubated for $10 \mathrm{~min}$ at $37^{\circ} \mathrm{C}$ with $3 \mu \mathrm{M}$ fluo-4 AM (Invitrogen S.R.L.) in an imaging buffer containing $137 \mathrm{mM}$ $\mathrm{NaCl}, 5 \mathrm{mM} \mathrm{KCl}, 1.2 \mathrm{mM} \mathrm{MgCl}, 0.44 \mathrm{mM} \mathrm{KH_{2 }} \mathrm{PO}_{4}$, $4.2 \mathrm{mM} \mathrm{NaHCO}_{3}, 5 \mathrm{mM}$ glucose, and $20 \mathrm{mM}$ HEPES $\mathrm{pH}$ 7.4. The cells were carefully washed with the imaging buffer after its removal. Calcium oscillations were then analyzed by means of an inverted epifluorescence microscope equipped with a top stage incubator (Tokai Hit INU-F1, Tokai Hit, Shizuoka-Ken, Japan) in order to keep cells in the optimal culturing environment. As an illumination source, we used a mercury arc discharge lamp and selected excitation and emission wavelengths with an FITC filter cube (EX 465-495 DM505 EM 515$555 \mathrm{~nm})$. Use was made of an 60X1.45NA objective (Nikon Instruments S.P.A., Firenze, Italy) and, in order to minimize phototoxicity and photobleaching, a backthinned electron multiplied CCD camera C9100-13 Imagem (Hamamatsu Photonics Italia S.R.L., Milano, Italy). After the first minute, required to achieve optimal culture conditions, intracellular fluorescence was continuously monitored (3 frames/sec) for $12 \mathrm{~min}$. In all experiments, during the first minute of recording, the cells were maintained in imaging buffer for the first $2 \mathrm{mi}$ nutes, after which they were stimulated with $10 \mathrm{nM}$ S100A8, $10 \mathrm{nM}$ S100A9 and $50 \mathrm{nM}$ NT-S100A8, alone or in combination with $0.02 \mathrm{ng} / \mathrm{ml}$ TGF $\beta 1$. For all stimuli, additions were made directly to the microscope chamber without interrupting the recording. The fluorescence signal was quantified by measuring the mean pixel value of a manually selected cellular area for each frame of the image stack using the HCimage system (Hamamatsu Photonics Italia S.R.L.). For all the experimental conditions, at least 3 independents sets of experiments were performed.

\section{Real time PCR (RT-PCR) for EMT markers}

BxPC3 and MiaPaCa2 cells $\left(300 \times 10^{3}\right)$ were seeded in six well dishes for 24 hours in their complete media. Cells remained non-stimulated (negative control) or were

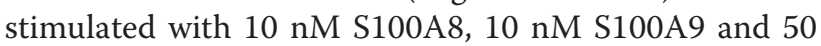
nM NT-S100A8, alone or combined with $0.02 \mathrm{ng} / \mathrm{ml}$ TGF $\beta 1$, for 72 hours. Following stimulation, the cells were collected with $0.25 \%$ trypsin ( $1 \mathrm{mM}$ EDTA) and centrifuged for $10 \mathrm{~min}$ at 4,000 rpm. Total RNA was extracted from cells using the High Pure RNA isolation kit (Roche, Monza, Italy), and reverse transcription was performed using $200 \mathrm{ng}$ of total RNA, M-MLV Transcriptase and $250 \mu \mathrm{M}$ random primers (Invitrogen S.R.L.). Quantitative Real-Time PCR analysis for CDH1 (E-cadherin), CDH2 (N-cadherin), SNAI1 (Snail), SNAI2 (Slug), TWIST1 (Twist), ZEB1, ZEB2, and B2M ( $\beta 2-\mathrm{mi}-$ cro-globulin) were performed with the LightCycler 480
Real-Time System (Roche Diagnostics, Mannheim, Germany). The primer sequences (shown in Additional file 10: Table S2) and the respective probes were designed using the Universal ProbeLibrary (Roche) and ProbeFinder software (http://www.roche-applied-science. $\mathrm{com} /$ ). Experimental procedures followed the standard protocol using the LightCycler 480 Probes Master (Roche). $\beta 2$-microglobulin (B2M) was included as a housekeeping gene control. At least three independent sets of experiments were performed in each experimental condition, and all real time PCR reactions were run in triplicate.

\section{Immunocytochemistry}

In order to investigate immunocytochemical reactions, control and stimulated cells were formalin-fixed and paraffin embedded before obtaining 4-5 mm-thick sections from each cell block. All immunocytochemical staining was performed automatically (Bondt-maX, Menarini, Florence, Italy) with primary antibodies: Ecadherin (DakoCytomation, Glostrup, Denmark) (1:200), N-cadherin (DakoCytomation) (1:100), Twist1 (Novocastra, Newcastle-upon-Tyne, UK)(1:600). Sections were then lightly counterstained with hematoxylin. E-cadherin and $\mathrm{N}$-cadherin immunoreactions were defined as immunoreactions detectable in the membrane while Twist was defined as a positive nuclear staining. At least three independent sets of experiments were performed in each experimental condition.

\section{MALDI-TOF/MS reflectron positive ion mode analysis}

Cell culture media were first desalted and purified by ZipTip C18 pipette tips, following the procedure described in the ZipTip user's guide. Five microliters of each purified peptide solution were added to $5 \mu \mathrm{l}$ of $\alpha$ cyano-4-hydroxycinnamic acid (HCCA) and $1 \mu \mathrm{l}$ of the resulting mixture was deposited in duplicate on the steel sample holder and allowed to dry. MALDI-TOF/MS measurements were performed using an Ultraflex II MALDI-TOF instrument (BrukerDaltonics, Bremen, Germany), operating in reflectron positive ion mode. Ions were formed using a pulsed UV laser $(\lambda=337 \mathrm{~nm})$ beam. The instrumental conditions were: IS1 $=25 \mathrm{kV}$; IS2 $=21.65 \mathrm{kV}$; reflectron potential $=26.3 \mathrm{kV}$; delay time $=$ 0 nsec. External mass calibration (Peptide Calibration Standard, BrukerDaltonics) was based on monoisotopic values of $[\mathrm{M}+\mathrm{H}]+$ of Angiotensin II, AngiotensinI, Substance P, Bombesin, ACTH clip (1-17), ACTH clip (18-39), Somatostatin 28 at $\mathrm{m} / \mathrm{z}$ 1046.5420, 1296.6853, 1347.7361, 1619.8230, 2093.0868, 2465.1990 and 3147.4714, respectively.

\section{MALDI-TOF/MS linear positive ion mode analysis}

S100A8, S100A9 and TGF $\beta 1$ and calcium ions $\left(\mathrm{CaCl}_{2}\right)$ were mixed at an equimolar concentration $(11.3 \mu \mathrm{M})$ in 
an aqueous solution. Each mixture was incubated overnight at $37^{\circ} \mathrm{C}$ prior to MALDI-TOF/MS analysis. S100A8, S100A9 and TGF $\beta 1$ mixtures were diluted $1 / 10$ in $50 \mu \mathrm{L}$ of $0.1 \%$ TFA aqueous solution, after which 5 microliters of each dilution were added to $5 \mu \mathrm{l}$ of Sinapinic acid (SA); $1 \mu \mathrm{l}$ of the resulting mixture was deposited in duplicate on the steel sample holder and allowed to dry. External mass calibration (Protein Calibration Standard II, BrukerDaltonics) was based on monoisotopic values of $[\mathrm{M}+\mathrm{H}]+$ of Trypsinogen, Protein A, Albumin-Bovine (BSA), at $\mathrm{m} / \mathrm{z}$ 23982, 44613, 66500, respectively. MALDI-TOF/MS measurements were performed using an Ultraflex II MALDITOF instrument (BrukerDaltonics), operating in linear positive ion mode. Ions were formed using a pulsed UV laser $(\lambda=337 \mathrm{~nm})$ beam. The instrumental conditions were: IS1 $=25 \mathrm{kV}$; IS2 $=23.35 \mathrm{kV}$; delay time $=70$ nsec. All chemicals and solvents were purchased from SigmaAldrich (Sigma Aldrich). One spectrum was collected for each sample, an average of 1,000 laser shots being obtained from the respective two replicate spots.

\section{Statistical analysis}

The statistical analysis of data was made using one-way analysis of variance (ANOVA), Bonferroni's test for pairwise comparisons, and Mann Whitney and Kruskal Wallis tests using the statistical software SPSS version 9.

\section{Additional files}

Additional file 1: Figure S1. Receptor for advanced glycation endproducts (RAGE) in PDAC cell lines. A) Western blot results obtained from PDAC cell lines (five millions in $\varnothing 10 \mathrm{~cm}$ Petri dishes) cultured for 24 hours in their respective complete media. Immunoblot was performed as described in Materials and Methods using Anti-RAGE (R\&D Systems, USA) at a 1:200 dilution. B) Columns show the mean optical densities (O.D.; ImageJ software, v 1.47) of RAGE immunoblot results, obtained from 5 independent experiments. Bars show standard deviations.

Additional file 2: Figure S2. MALDI-TOF-MS/MS sequencing of the $2280 \mathrm{~m} / \mathrm{z}$ peptide. S100A8 was incubated with Capan1 conditioned media for 48 hours at $37^{\circ} \mathrm{C}$ before MALDI-TOF-MS/MS sequencing of the degration peptide at $1435 \mathrm{~m} / \mathrm{z}$. De novo sequencing was obtained by Mascot Distiller (v 2.5.0.0).

Additional file 3: Figure S3. MALDI-TOF-MS/MS sequencing of the $1435 \mathrm{~m} / \mathrm{z}$ peptide. S100A8 was incubated with Capan1 conditioned media for 48 hours at $37^{\circ} \mathrm{C}$ before MALDI-TOF-MS/MS sequencing of the degration peptide at $1435 \mathrm{~m} / \mathrm{z}$. De novo sequencing was obtained by Mascot Distiller (v 2.5.0.0).

Additional file 4: Figure S4. Differential effects of S100 proteins and TGF $\beta 1$ on STAT signaling. BXPC3, Capan1, MiaPaCa2 and Panc1 remained unstimulated (NC, negative control) or were stimulated for 10 minutes with $50 \mathrm{mU}$ insulin (positive control), $0.02 \mathrm{ng} / \mathrm{ml}$ TGF $\beta 1$ alone or combined with 50 nM NT-S100A8, 10 nM S100A8, 10 nM S100A9, 10 nM S100A8/A9 complex. Western blot shows Stat3 phosphorylation at Tyr ${ }^{705}$ site and the corresponding $\beta$-actin, used as control. Histograms show semi-quantification of band intensities after normalization against the negative control (O.D.; ImageJ software, v 1.47). Columns indicate mean values, bars indicate SD from two independ experiments.

Additional file 5: Figure S5. Differential effects of S100 proteins and TGF $\beta 1$ on NF-KB, Akt, mTOR and STAT signaling in Smad4 expressing BXPC3 cells. BXPC3-SMAD4+ cells remained unstimulated (NC, negative control) or were stimulated for 10 minutes with $50 \mathrm{mU}$ insulin (positive control), $0.02 \mathrm{ng} / \mathrm{ml}$ TGF $\beta 1$ alone or combined with $50 \mathrm{nM}$ NT-S100A8, $10 \mathrm{nM}$ S100A8, 10 nM S100A9, 10 nM S100A8/A9 complex. A: IkB-a phosphorylation at Ser ${ }^{32}$ site and corresponding $\beta$-actin. B: Akt phosphorylation sites Thr ${ }^{308}$ and Ser ${ }^{473}$ and corresponding non-phosphorylated Akt (panAKT). C: mTOR phosphorylation sites Ser ${ }^{2481}$ and Ser ${ }^{2448}$, phosphorylation of S6 Ribosomal Protein at the Ser ${ }^{235 / 236}$ site (pS6RP) and $\beta$-actin. D: Stat3 phosphorylation at Tyr ${ }^{705}$ site and corresponding $\beta$-actin. Histograms show semi-quantification of band intensities after normalization against the negative control (O.D; ImageJ software, v 1.47). Columns indicate mean values, bars indicate SD from two independ experiments.

Additional file 6: Table S1. XTT cell viability assay results.

Additional file 7: Figure S6. XTT cell viability assay results. BXPC3 (empty columns) and BXPC3-SMAD4+ (filled columns) were seeded in a 96 well culture plate (2000 cells/well) and cultured for 48 hours, $\mathbf{A}$ : in absence (control) or in presence of TGFB1 $(0.02 \mathrm{ng} / \mathrm{ml})$ and NT-S100A8 $(50 \mathrm{nM})$, alone or combined; $\mathbf{B}$ : in absence (control) or in presence of TGF $\beta 1(0.02 \mathrm{ng} / \mathrm{ml})$ and S100A8 (10 nM) and S100A9 (10 nM), alone or combined. In each experimental set, the median value of $\mathrm{Abs}_{450 \mathrm{~nm}}$ of untreated cells was calculated and used as reference. All the other values were expressed as percentage to the reference. Columns and bars show mean and standard errors, respectivelty. Student's $t$ test: $*=p<0.05$.

Additional file 8: Figure S7. $\mathrm{N}$-cadherin immunostain. $\mathrm{BxPC}$ cells treated with NT-S100A8, S100A8, S100A9, S100A8/A9 alone (left panels) or combined (right panels) with TGF $\beta 1$.

Additional file 9: Figure S8. Schematic representation of results. This study demonstrates that metastatic PDAC cells express S100A8/A9 mRNA transcripts and that both primary and metastatic PDAC-derived proteases cause the release of small peptides from the $\mathrm{N}$-terminal sequence of S100A8. S100A8, S100A9 and S100A8/A9 heterocomplex share many effects on NF-KB, Akt and mTOR signaling in PDAC cells and these effects are dependent on SMAD4 expression (Smad4+=Smad4 expressing PDAC cells; Smad4- = Smad4 non expressing PDAC cells). The effects of the 14 aminoacid N-terminal sequence of S100A8 (NT-S100A8) may overlap those of the entire S100A8 or may differ. Continuous arrows indicate stimulation, dotted arrows indicate inhibition, dotted lines indicate no effect. TGF $\beta 1$ may counteract S100 proteins effects on NF-KB or Akt in SMAD4+, not in SMAD4-, PDAC cells. "Yes" indicates that TGF $\beta 1$ counteracts, "No" indicates that TGF $\beta 1$ does not counteract that specific effect of S100 proteins. *: only in Capan1 cell line.

Additional file 10: Supplementary Materials and Methods. Table S2. Primers used for qRT-PCR analysis of the EMT genes.

\section{Abbreviations}

RAGE: Receptor for advanced glycation endproducts; mTOR: Mammalian target of rapamycin; NF-KB: Nuclear factor kappa-light-chain-enhancer of activated B cells; MALDI-TOF/MS: Matrix-assisted laser desorption ionizationtime-of-flight mass spectrometer.

\section{Competing interests}

The authors declare they have no conflicting financial interests.

\section{Author's contributions}

Conception and design of the study: DB, DB, AP, SM. Generation, collection, assembly, analysis and/or interpretation of data: DB, DB, AP, SM, CFZ, PF, EG, $M S, F S, F N, M F, M P, S D$. Drafting and revision of the manuscript: DB, DB, AP, SM, AF. Approval of the final version of the manuscript: SP, MP. All authors read and approved the final manuscript.

\section{Acknowledgements}

The Authors thank Laura Molin and Roberta Seraglia (CNR-ISTM, Padova, Italy), Alda Di Chiara and Girolamo Pavanello (SIPRES, Gruppo Pavanello, Padova, Italy), Carlo Reggiani (Department of Biomedical Sciences DSB, University of Padova, Padova, Italy), Stefano Piccolo (Department of Molecular Medicine, University of Padova, Padova, Italy) for their technical and intellectual support. Thanks also go to the Proteomic Center of Padova University for the use of the MALDI-TOF/TOF mass spectrometer. The study was financed by Associazione Wirsung Onlus (Padova, Italy). 


\section{Author details}

'Department of Laboratory Medicine, University-Hospital of Padova, Via Giustiniani 2, 35128 Padova, Italy. ²Department of Medicine - DIMED, University of Padova, Padova, Italy. ${ }^{3}$ Department of Biomedical Sciences - DSB, University of Padova, Padova, Italy. ${ }^{4}$ Department of Molecular Medicine, University of Padova, Padova, Italy. ${ }^{5}$ Associazione Wirsung Onlus, Padova, Italy.

\section{Received: 10 September 2013 Accepted: 8 March 2014}

Published: 26 March 2014

\section{References}

1. Malvezzi M, Arfé A, Bertuccio P, Levi F, La Vecchia C, Negri E: European cancer mortality predictions for the year 2011. Ann Oncol 2011, 22:947-956

2. Siegel R, Naishadham D, Jemal A: Cancer statistics, 2012. CA Cancer J Clin 2012, 62:10-29.

3. Hidalgo M: Pancreatic cancer. N Engl J Med 2010, 362:1605-1617.

4. Bardeesy N, DePinho RA: Pancreatic cancer biology and genetics. Nat Rev Cancer 2002, 2:897-909.

5. Aguirre AJ, Bardeesy N, Sinha M, Lopez L, Tuveson DA, Horner J, Redston MS, DePinho RA: Activated Kras and Ink4a/Arf deficiency cooperate to produce metastatic pancreatic ductal adenocarcinoma. Genes Dev 2003, 17:3112-3126

6. Bardeesy N, Aguirre AJ, Chu GC, Cheng KH, Lopez LV, Hezel AF, Feng B, Brennan C, Weissleder R, Mahmood U, Hanahan D, Redston MS, Chin L, DePinho RA: Both p16(Ink4a) and the p19(Arf)-p53 pathway constrain progression of pancreatic adenocarcinoma in the mouse. Proc Natl Acad Sci USA 2006, 103:5947-5952.

7. Ying H, Elpek KG, Vinjamoori A, Zimmerman SM, Chu GC, Yan H, FletcherSananikone E, Zhang H, Liu Y, Wang W, Ren X, Zheng H, Kimmelman AC, Paik JH, Lim C, Perry SR, Jiang S, Malinn B, Protopopov A, Colla S, Xiao Y, Hezel AF, Bardeesy N, Turley SJ, Wang YA, Chin L, Thayer SP, DePinho RA: PTEN is a major tumor suppressor in pancreatic ductal adenocarcinoma and regulates an NF-KB-cytokine network. Cancer Discov 2011, 1:158-169.

8. Bardeesy N, Cheng KH, Berger JH, Chu GC, Pahler J, Olson P, Hezel AF Horner J, Lauwers GY, Hanahan D, DePinho RA: Smad4 is dispensable for normal pancreas development yet critical in progression and tumor biology of pancreas cancer. Genes Dev 2006, 20:3130-3146.

9. Yachida S, lacobuzio-Donahue CA: The pathology and genetics of metastatic pancreatic cancer. Arch Pathol Lab Med 2009, 133:413-422.

10. lacobuzio-Donahue CA, Fu B, Yachida S, Luo M, Abe H, Henderson CM Vilardell F, Wang Z, Keller JW, Banerjee P, Herman JM, Cameron JL, Yeo CJ, Halushka MK, Eshleman JR, Raben M, Klein AP, Hruban RH, Hidalgo M, Laheru D: DPC4 gene status of the primary carcinoma correlates with patterns of failure in patients with pancreatic cancer. J Clin Oncol 2009. 27:1806-1813.

11. Blackford A, Serrano OK, Wolfgang CL, Parmigiani G, Jones S, Zhang X, Parsons DW, Lin JC, Leary RJ, Eshleman JR, Goggins M, Jaffee EM, lacobuzioDonahue CA, Maitra A, Cameron JL, Olino K, Schulick R, Winter J, Herman JM, Laheru D, Klein AP, Vogelstein B, Kinzler KW, Velculescu VE, Hruban RH: SMAD4 gene mutations are associated with poor prognosis in pancreatic cancer. Clin Cancer Res 2009, 15:4674-4679.

12. Bierie B, Moses HL: Tumour microenvironment: TGFbeta: the molecular Jekyll and Hyde of cancer. Nat Rev Cancer 2006, 6:506-520.

13. Jones S, Zhang X, Parsons DW, Lin JC, Leary RJ, Angenendt P, Mankoo P, Carter H, Kamiyama H, Jimeno A, Hong SM, Fu B, Lin MT, Calhoun ES, Kamiyama M, Walter K, Nikolskaya T, Nikolsky Y, Hartigan J, Smith DR Hidalgo M, Leach SD, Klein AP, Jaffee EM, Goggins M, Maitra A, lacobuzioDonahue C, Eshleman JR, Kern SE, Hruban RH, et al: Core signaling pathways in human pancreatic cancers revealed by global genomic analyses. Science 2008, 321:1801-1806

14. Stover DG, Bierie B, Moses HL: A delicate balance: TGF-beta and the tumor microenvironment. J Cell Biochem 2007, 101:851-861.

15. Freudlsperger C, Bian Y, Contag Wise S, Burnett J, Coupar J, Yang X, Chen Z, Van Waes C: TGF- $\beta$ and NF-KB signal pathway cross-talk is mediated through TAK1 and SMAD7 in a subset of head and neck cancers. Oncogene 2013, 32:1549-1559.

16. Achyut BR, Yang L: Transforming growth factor- $\beta$ in the gastrointestinal and hepatic tumor microenvironment. Gastroenterology 2011, 141:1167-1178
17. Fuxe J, Vincent T, Garcia de Herreros A: Transcriptional crosstalk between TGF- $\beta$ and stem cell pathways in tumor cell invasion: role of EMT promoting Smad complexes. Cell Cycle 2010, 9:2363-2374.

18. Shin JA, Hong OK, Lee HJ, Jeon SY, Kim JW, Lee SH, Cho JH, Lee JM, Choi $\mathrm{YH}$, Chang SA, Son HY, Kim JH, Yoon KH: Transforming growth factor- $\beta$ induces epithelial to mesenchymal transition and suppresses the proliferation and transdifferentiation of cultured human pancreatic duct cells. J Cell Biochem 2011, 112:179-188.

19. Zhu L, Qin H, Li PY, Xu SN, Pang HF, Zhao HZ, Li DM, Zhao Q: Response gene to complement-32 enhances metastatic phenotype by mediating transforming growth factor beta-induced epithelial-mesenchymal transition in human pancreatic cancer cell line BxPC-3. J Exp Clin Cancer Res 2012, 31:29.

20. Maitra A, Hruban RH: Pancreatic cancer. Annu Rev Pathol 2008, 3:157-188.

21. Ijichi H, Chytil A, Gorska AE, Aakre ME, Bierie B, Tada M, Mohri D, Miyabayashi K, Asaoka Y, Maeda S, Ikenoue T, Tateishi K, Wright V, Koike K, Omata M, Moses $\mathrm{HL}$ : Inhibiting Cxcr2 disrupts tumor-stromal interactions and improves survival in a mouse model of pancreatic ductal adenocarcinoma. J Clin Invest 2011, 121:4106-4117.

22. Shields MA, Dangi-Garimella S, Redig AJ, Munshi HG: Biochemical role of the collagen-rich tumour microenvironment in pancreatic cancer progression. Biochem J 2012, 441:541-552.

23. Aoyagi Y, Oda T, Kinoshita T, Nakahashi C, Hasebe T, Ohkohchi N, Ochiai A Overexpression of TGF-beta by infiltrated granulocytes correlates with the expression of collagen mRNA in pancreatic cancer. Br J Cancer 2004, 91:1316-1326.

24. Goyette J, Geczy CL: Inflammation-associated S100 proteins: new mechanisms that regulate function. Amino Acids 2011, 41:821-842.

25. Engelkamp D, Schafer BW, Mattei MG, Erne P, Heizmann CW: Six S100 genes are clustered on human chromosome 1q21: identification of two genes coding for the two previously unreported calcium-binding proteins S100D and S100E. Proc Natl Acad Sci USA 1995, 90:6547-6551.

26. Gronwald J, Storkel S, Holtgreve-Grez H, Hadaczek P, Brinkschmidt C, Jauch A, Lubinski J, Cremer T: Comparison of DNA gains and losses in primary renal clear cell carcinomas and metastatic sites: importance of $1 \mathrm{q}$ and $3 p$ copy number changes in metastatic events. Cancer Res 1997, 57:481-487.

27. Meza-Zepeda LA, Forus A, Lygren B, Dahlberg AB, Godager LH, South AP, Marenholz I, Lioumi M, Flørenes VA, Maelandsmo GM, Serra M, Mischke D, Nizetic D, Ragoussis J, Tarkkanen M, Nesland JM, Knuutila S, Myklebost O: Positional cloning identifies a novel cyclophilin as a candidate amplified oncogene in 1q21. Oncogene 2002, 21:2261-2269.

28. Ghavami S, Chitayat S, Hashemi M, Eshraghi M, Chazin WJ, Halayko AJ, Kerkhoff C: S100A8/A9: a Janus-faced molecule in cancer therapy and tumorgenesis. Eur J Pharmacol 2009, 625:73-83.

29. Ehrchen JM, Sunderkötter C, Foell D, Vogl T, Roth J: The endogenous Tolllike receptor 4 agonist S100A8/S100A9 (calprotectin) as innate amplifie of infection, autoimmunity, and cancer. J Leukoc Biol 2009, 86:557-566.

30. Gebhardt C, Riehl A, Durchdewald M, Németh J, Fürstenberger G, Müller-Decker K, Enk A, Arnold B, Bierhaus A, Nawroth PP, Hess J, Angel P: RAGE signalling sustains inflammation and promotes tumor development. J Exp Med 2008, 205:275-285.

31. Sheikh AA, Vimalachandran D, Thompson CC, Jenkins RE, Nedjadi T, Shekouh A, Campbell F, Dodson A, Prime W, Crnogorac-Jurcevic T, Lemoine NR, Costello E: The expression of S100A8 in pancreatic cancer-associated monocytes is associated with the Smad4 status of pancreatic cancer cells. Proteomics 2007, 7:1929-1940.

32. Shen J, Person MD, Zhu J, Abbruzzese JL, Li D: Protein expression profiles in pancreatic adenocarcinoma compared with normal pancreatic tissue and tissue affected by pancreatitis as detected by two-dimensional gel electrophoresis and mass spectrometry. Cancer Res 2004, 64:9018-9026.

33. Ang CW, Nedjadi T, Sheikh AA, Tweedle EM, Tonack S, Honap S, Jenkins RE, Park BK, Schwarte-Waldhoff I, Khattak I, Azadeh B, Dodson A, Kalirai $H_{\text {, }}$ Neoptolemos JP, Rooney PS, Costello E: Smad4 loss is associated with fewer S100A8-positive monocytes in colorectal tumors and attenuated response to S100A8 in colorectal and pancreatic cancer cells. Carcinogenesis 2010, 31:1541-1551.

34. Basso D, Greco E, Padoan A, Fogar P, Scorzeto M, Fadi E, Bozzato D, Moz S, Navaglia F, Zambon CF, Seraglia R, De Carlo E, Valerio A, Reggiani C, Pedrazzoli S, Plebani M: Altered intracellular calcium fluxes in pancreatic cancer induced diabetes mellitus: relevance of the S100A8 N-terminal peptide (NT-S100A8). J Cell Physiol 2011, 226:456-468. 
35. Rey O, Young SH, Jacamo R, Moyer MP, Rozengurt E: Extracellular calcium sensing receptor stimulation in human colonic epithelial cells induces intracellular calcium oscillations and proliferation inhibition. J Cell Physiol 2010, 225:73-83.

36. Soderling TR: The Ca-calmodulin-dependent protein kinase cascade. Trends Biochem Sci 1999, 24:232-236.

37. Frégeau MO, Régimbald-Dumas Y, Guillemette G: Positive regulation of inositol 1,4,5-trisphosphate-induced $\mathrm{Ca} 2+$ release by mammalian target of rapamycin (mTOR) in RINm5F cells. J Cell Biochem 2011, 112:723-733.

38. Régimbald-Dumas Y, Frégeau MO, Guillemette G: Mammalian target of rapamycin (mTOR) phosphorylates inositol 1,4,5-trisphosphate receptor type 2 and increases its $\mathrm{Ca}(2+)$ release activity. Cell Signal 2011, 23:71-79.

39. Ming M, Manzini I, Le W, Krieglstein K, Spittau B: Thapsigargin-induced Ca2 + increase inhibits TGF $\beta 1$-mediated Smad 2 transcriptional responses via Ca2+/calmodulin-dependent protein kinase II. J Cell Biochem 2010, 111:1222-1230.

40. Wicks SJ, Lui S, Abdel-Wahab N, Mason RM, Chantry A: Inactivation of smad-transforming growth factor beta signaling by $\mathrm{Ca}(2+)$-calmodulindependent protein kinase II. Mol Cell Biol 2000, 20:8103-8111.

41. Funel N, Costa F, Pettinari L, Taddeo A, Sala A, Chiriva-Internati M, Cobos E, Colombo G, Milzani A, Campani D, Dalle-Donne I, Gagliano N: Ukrain affects pancreas cancer cell phenotype in vitro by targeting MMP-9 and intra-/ extracellular SPARC expression. Pancreatology 2010, 10:545-552.

42. Sipos B, Möser S, Kalthoff H, Török V, Löhr M, Klöppel G: A comprehensive characterization of pancreatic ductal carcinoma cell lines: towards the establishment of an in vitro research platform. Virchows Arch 2003 442:444-452.

43. Manning BD, Cantley LC: AKT/PKB signaling: navigating downstream. Cell 2007, 129:1261-1274.

44. Hiratsuka S, Ishibashi S, Tomita T, Watanabe A, Akashi-Takamura S, Murakami M, Kijima H, Miyake K, Aburatani H, Maru Y: Primary tumours modulate innate immune signalling to create pre-metastatic vascular hyperpermeability foci. Nat Commun 1853, 2013:4.

45. Riehl A, Németh J, Angel P, Hess J: The receptor RAGE: bridging inflammation and cancer. Cell Commun Signal 2009, 7:12.

46. Moore PS, Sipos B, Orlandini S, Sorio C, Real FX, Lemoine NR, Gress T, Bassi C, Klöppel G, Kalthoff H, Ungefroren H, Löhr M, Scarpa A: Genetic profile of 22 pancreatic carcinoma cell lines. Analysis of K-ras, p53, p16 and DPC4/ Smad4. Virchows Arch 2001, 439:798-802.

47. Suemizu H, Monnai M, Ohnishi Y, Ito M, Tamaoki N, Nakamura M: Identification of a key molecular regulator of liver metastasis in human pancreatic carcinoma using a novel quantitative model of metastasis in NOD/SCID/gammacnull (NOG) mice. Int J Oncol 2007, 31:741-751.

48. Ying H, Da L, Yu-xiu S, Yu X, Li-xia L, Li-mei X, Wei-dong R: TLR4 mediates MAPK-STAT3 axis activation in bladder epithelial cells. Inflammation 2013, 36:1064-1074

49. Matthaios D, Zarogoulidis P, Balgouranidou I, Chatzaki E, Kakolyris S: Molecular pathogenesis of pancreatic cancer and clinical perspectives. Oncology 2011, 81:259-272.

50. Chen El, Kridel SJ, Howard EW, Li W, Godzik A, Smith JW: A unique substrate recognition profile for matrix metalloproteinase-2. J Biol Chem 2002, 277:4485-4491.

51. Gurumurthy S, Bardeesy N: Uncapping NF-KB activity in pancreatic cancer. EMBO J 2011, 30:1-2.

52. Xu X, Ehdaie B, Ohara N, Yoshino T, Deng CX: Synergistic action of Smad4 and Pten in suppressing pancreatic ductal adenocarcinoma formation in mice. Oncogene 2010, 29:674-686.

53. Zoncu R, Efeyan A, Sabatini DM: mTOR: from growth signal integration to cancer, diabetes and ageing. Nat Rev Mol Cell Biol 2011, 12:21-35.

54. Le Gendre O, Sookdeo A, Duliepre SA, Utter M, Frias M, Foster DA: Suppression of AKT phosphorylation restores rapamycin-based synthetic lethality in SMAD4-defective pancreatic cancer cells. Mol Cancer Res 2013, 11:474-481.

55. Santamaria-Kisiel L, Rintala-Dempsey AC, Shaw GS: Calcium-dependent and -independent interactions of the S100 protein family. Biochem J 2006, 396:201-214.

56. Qin $Q, X u Y, H e T$, Qin $C, X u$ J: Normal and disease-related biological functions of Twist1 and underlying molecular mechanisms. Cell Res 2012, 22:90-106.

57. Lee SH, Lee SJ, Jung YS, Xu Y, Kang HS, Ha NC, Park BJ: Blocking of p53-Snail binding, promoted by oncogenic K-Ras, recovers p53 expression and function. Neoplasia 2009, 11:22-31.
58. Klingelhöfer J, Møller HD, Sumer EU, Berg CH, Poulsen M, Kiryushko D, Soroka V, Ambartsumian N, Grigorian M, Lukanidin EM: Epidermal growth factor receptor ligands as new extracellular targets for the metastasispromoting S100A4 protein. FEBS J 2009, 276:5936-5948.

59. Gupta AA, Chou RH, Li H, Yang LW, Yu C: Structural insights into the interaction of human $\mathrm{S} 100 \mathrm{~B}$ and basic fibroblast growth factor (FGF2): effects on FGFR1 receptor signaling. Biochim Biophys Acta 1834, 2013:2606-2619.

60. Riuzzi F, Sorci G, Donato R: S100B protein regulates myoblast proliferation and differentiation by activating FGFR1 in a bFGF-dependent manner. J Cell Sci 2011, 124:2389-2400.

61. Dupont S, Mamidi A, Cordenonsi M, Montagner M, Zacchigna L, Adorno M, Martello G, Stinchfield MJ, Soligo S, Morsut L, Inui M, Moro S, Modena N, Argenton F, Newfeld SJ, Piccolo S: FAM/USP9x, a deubiquitinating enzyme essential for TGFbetasignaling, controls Smad4 monoubiquitination. Cell 2009, 136:123-135.

\section{doi:10.1186/1478-811X-12-20}

Cite this article as: Basso et al:: Inflammation and pancreatic cancer: molecular and functional interactions between S100A8, S100A9, NTS100A8 and TGF $\beta 1$. Cell Communication and Signaling 2014 12:20.

\section{Submit your next manuscript to BioMed Central and take full advantage of:}

- Convenient online submission

- Thorough peer review

- No space constraints or color figure charges

- Immediate publication on acceptance

- Inclusion in PubMed, CAS, Scopus and Google Scholar

- Research which is freely available for redistribution

Submit your manuscript at www.biomedcentral.com/submit
C Biomed Central 